\title{
THE REFORM OF COMMON LAW PLEADING IN MASSACHUSETTS 1760-1830: ADJUDICATION AS A PRELUDE TO LEGISLATION
}

\author{
WILLIAM E. NELSON†
}

For generations students of the American legal system who have studied the history of the law of civil pleading and procedure have devoted most of their attention to one single incident - the enactment of the Field Code of Procedure in New York in 1848. The interpretation advanced has been that prior to the 1840's the common law system of pleading "taken from England served well enough, and the people manifested little inclination to take up the burden of revision." Instead they "were too busily concerned with financial, social, and industrial problems to permit of any great activity in the direction of reforming legal procedure." But, then, David Dudley Field with the aid of a tiny band of lawyer-reformers, perceiving that the common law rules of pleading were outmoded and unduly expensive, conceived the Code and induced the legislatures of New York and most other states to adopt it. ${ }^{2}$

This story of Field and his Code has undoubtedly inspired generations of practitioners with faith that thought and effort are the chief ingredients of successful reform. A comprehensive

†Assistant Professor of Law, University of Pennsylvania. A.B. 1962, Hamilton College; LL.B. 1965, New York University; Ph.D. 1971, Harvard University. Member, New York Bar.

This article is excerpted from a book about the legal history of Massachusetts between 1760 and 1830 , on which the author is currently working. Research on the book was financed in part by grants from the American Bar Foundation and from the Charles Warren Fund of the Harvard Law School.

${ }^{1}$ E. Sunderland, Cases and Materials on Code Pleading 3 (2d ed. 1940).

${ }^{2}$ For discussions of the origins of the Field Code, see C. CLARK, HANDBOOK OF THE LAW OF CODE Pleading 17-19 (1928); R. FIELD \& B. KAPLAN, MATERIALS FOR A Basic Course in Civil Procedure 313 (temp. 2d ed. 1968); J. Koffler \& A. RePpy, HANDBoOK OF Common Law Pleading 3-4 (1969); E. Sunderland, supra note 1, at 3; Pound, David Dudley Field: An Appraisal in David Dudley Field: Centenary EsSaYs 1 (1949); Hepburn, The Historical Development of Code Pleading in A merica and England, in 2 SELECT ESSAYS IN ANGLO-AMERICAN LEGAL HISTORY 657 (1908).

The common law system continued in England throughout the first third of the 19th century. While the demand for reform developed early in the century, the first actual reforms were the Hilary Reforms of 1834. This series of reforms abolished the technicalities in the commencement and the conclusion of pleas, simplified the form of demurrer and joinder in demurrer, specified the scope of general issues in the different 
study of the surviving records of trial and appellate courts in Massachusetts from 1760 to 1830 suggests, however, that the traditional view of the impact of the Field Code may be mistaken. At least in Massachusetts, the abandonment of the system of common law pleading did not occur suddenly. Instead, the common law system was gradually transformed during a period of more than a half century into something like a modern system of notice pleading. The transformation, moreover, was largely the work of the courts and was not given statutory form until it was nearly complete.

\section{COMMON LAW PLEADING IN MASSACHUSETTS BEFORE THE REVOLUTION}

As early as the time of the American Revolution, lawyers and laymen alike were aware of the needless expense of litigation. One writer in 1770 , for example, told a correspondent that "[1] aw suits are what we wish to avoid and always advise our friends against it, as tedious and very expensive. ..."3 In part, the expense of litigation was a product of the fees paid to lawyers and court officers. Although lawyers' fees were not high, court fees were. Clerks', justices' and other fees due upon the docketing of an action were higher, for example, than the fee that a lawyer received for trying the action. ${ }^{4}$ Indeed, in hundreds of cases the various court fees, all of which had to be paid by the losing party, were greater than the sum which the plaintiff recovered as damages. ${ }^{5}$ Another element of expense arose from

forms of action, specified when several pleas could be used, and clarified when several counts could be employed in the declaration. E. SUNDERLAND, supra note 1 , at 3 . The effect of the reforms was minimal. One commentator has argued that the new rules retarded the progress of reform by postponing the real reform of common law pleading for another 20 years. C. HePBURN, THE HISTORICAL DEVELOPMENT OF CODE PLEADING IN AMERICA AND ENGLAND 76-77 (1897). The major reforms of English pleading came with the Common Law Procedure Acts of 1852, 1854 and 1860 and the Supreme Court of Judicature Acts of 1873 and 1875, with the 1873 Act "sweep[ing] away the English system of common law pleading even more completely than our codes have swept it away." Hepburn, The Historical Development of Code Pleading in America and England, in 2 Select Essays in ANglo-American Legal History 680 (1908). See J. Koffler \& A. REPPY, supra at 4.

${ }^{3}$ Letter from Anderson Bannatyne \& Co., Glasgow, to John Russell, Plymouth, June 5, 1770, in Plymouth Notary Public Records, 1768-1830 (mss. in Pilgrim Hall, Plymouth, Mass.).

${ }^{4}$ Various costs of litigation are discussed in detail in 1 LEGAL PAPERS OFJOHN ADAMS 1 xix-1 xxii (L. Wroth \& H. Zobel eds. 1965) [hereinafter cited as LEGAL PAPERS].

${ }^{5}$ See, e.g., Freeman v. Bradbury, [June 1774] Cumb. Super. Ct. 226 (damages of 30s; costs of L24 3s. 7d.); Reynolds v. Hall, [July 1766] Suff. Super. Ct. 20 (damages of L3 ls. 4d.; costs of L6 14s. 7d.); Bacon v. Nurse, [Sept. 1760] Worc. Super. Ct. 116 (damages of L2 15s. 4d.; costs of L15 15s. $6 \mathrm{~d}$.). 
peculiar Massachusetts rules giving every litigant a right to have his case tried twice. Thus, after he had lost his suit before a jury in a county Court of Common Pleas, he had a right to a trial de novo before another jury upon appeal to the provincial Superior Court of Judicature. If the verdicts of the two juries were inconsistent, he could obtain a third trial, again in the Superior Court, by bringing what was known as an action of review. ${ }^{6}$ Multiple trials, of course, multiplied fees.

The final element contributing to the expense of litigation was the system of common law pleading. The rules of pleading in use in Massachusetts at the time of the Revolution were outmoded and unduly technical. Although they may at one time have functioned in a practical way, rules dealing with matters such as the forms of action, service of process, joinder and identification of parties, and other procedural niceties had ceased to do so by the second half of the eighteenth century. These complex and technical rules did, however, introduce wasteful expense into the litigation process by producing needless dismissals and reinstitutions of suits. ${ }^{7}$

The common law forms of action were in full vigor in preRevolutionary Massachusetts, except in actions to try title to land. All of the actions commonly in use in England, such as trespass, trover, case, debt, covenant, assumpsit and replevin were also in use in Massachusetts, and one even finds obscure actions, such as recout, in occasional use. ${ }^{8}$ Under the common law system of pleading a plaintiff was required to name the form of action under which he was bringing his suit. If he did "not name ... his plea,"9 "give ... any name to this his Action,"10 or "declare... in an action of Debt or Trespass on the Case, or in any other Action or Plea known in the Register or in the Law,"ll

${ }^{6}$ The jurisdiction and practice of the courts in pre-Revolutionary Massachusetts, including the rights of litigants to take appeals, are discussed in 1 LEGAL PAPERS, supra note 4 , at xxxviii-xliv.

${ }^{7}$ Writs that were technically insufficient were abated, but abatement normally did not bar reinstitution of a suit by the filing of a new and technically sufficient writ. See id. xl v. See also Lovell v. Doble, Quincy 88 (1763).

${ }^{8}$ Reed v. Riddan, [Dec. 1761] Essex C.P. 93. Some writs, however, served different functions in Massachusetts than they had served in England. For example, entry, which had become obsolete in 18 th-century England, see T. PLUCKNETT, A CONCISE HISTORY OF THE COMMON LAW 373 (5th ed. 1956), became in Massachusetts an all-purpose writ in the nature of case for the recovery of land. See A. STEARnS, A Summary OF THE LAw AND PRACTICE OF REAL ACTIONS 507-08 (1824). Replevin, which lay in England only for wrongful distress, see T. PLUCKNETT, supra, at 368, had become a general writ for litigating property in chattels. See Scott v. Tirrell, [Aug. 1773] Suff. Super. Ct. 104; Sixley v. Brown, [Sept. 1767] Berk. C.P. 428.

${ }^{9}$ Watson v. Bliss, [Dec. 1764] Bris. C.P. 207.

${ }^{10}$ Atkins v. Roby, [Jan. 1767] Suff. C.P. Files.

"Hunt v. Fay, [Nov. 1771] Msex. C.P. Files. 
his writ would be abated. Writs were also abated when a plaintiff brought the wrong cause of action-trespass, for example, instead of case, for obstructing the flow of water to a mill dam; ${ }^{12}$ case, instead of debt, on a bond $;^{13} \mathrm{debt}$, instead of trespass, for a statutory penalty for cutting the plaintiff's trees; $;^{14}$ debet and detinet, a variety of debt, instead of detinet only, on an administrator's bond. ${ }^{15}$

Each form of action, moreover, had its own appropriate form of general denial, so called because it imported an absolute and complete denial by a defendant of each and every allegation in a plaintiff's declaration. For example, in trespass, either vi et armis or on the case, the appropriate form of general denial was not guilty; in debt, owes nothing; in debt on a bond, it is not the defendant's deed; in assumpsit, never promised. If the defendant pleaded the wrong general issue, as, for example, not guilty to a plea of assumpsit or owes nothing to a plea of trespass, or if the defendant pleaded a sham issue, such as that he had no money, that he was a Son of Liberty and therefore ought not be sued ${ }^{16}$ or, as John Adams colorfully pleaded in two cases, "Law is perfect reason without passion,"17 and "the Law of nature is common to brutes \& men,"18 then judgment would be given upon demurrer for the plaintiff. Of course, lawyers had little difficulty in pleading the correct general issue, since the relevant rules of law were clear and simple. However, in the Court of Common Pleas they often pleaded the wrong general issue in order to secure a judgment from which they could appeal to the Superior Court without having to go through the mechanism of a full trial. ${ }^{19}$

If a defendant did not wish to plead the general issue, he could plead specially. Although special pleading was used only rarely before the Revolution, its use became more frequent thereafter. ${ }^{20}$ Special pleas could be of a great variety, depending upon the circumstances of a defendant's case. A defendant might

${ }^{12}$ See Sawyer v. Farnham, [June 1765] Essex Super. Ct. 187.

${ }^{13}$ See Bush v. Fellows, [Nov. 1771] Berk. C.P. 433 .

${ }_{15}^{14} \mathrm{See}$ Owen v. Lee, [Aug. 1761] Hamp. C.P. 237.

${ }^{15}$ See Ross v. Willson, [Sept. 1766] Berk. C.P. 362; Fonda v. Lee, [Apr. 1765] Berk. C.P. 639, rev'd on default, [Sept. 1765] Hamp. Super. Ct. 285. See also Bicknall v. Draper, [Oct. 1761] Bris. Super. Ct. 269 (abated for calling writ "plea of review of plea of debt," instead of "plea of review of plea of review of plea of debt").

${ }^{16}$ See Boyce v. Spear, [Dec. 1766] Ply. C.P. 226.

${ }^{17}$ Clap v. Stockbridge, [Apr. 1768] Ply. C.P. 376.

${ }^{18}$ Barker v. Elmes, [Apr. 1768] Ply. C.P.376.

${ }^{19}$ See generally 1 LEGAL PAPERS, supra note 4, at xlvi.

${ }^{20}$ The absence of special pleading in the pre-Revolutionary period, noted in 1 LEGAL PAPERS, supra note 4, at 28-29, has been confirmed by the present author's research. For one of the rare examples in pre-Revolutionary Massachusetts of special pleading beyond the replication, see T. PARSONS, PRECEDENTS No. 71 (mss. in Harvard Law. School 
plead an accord and satisfaction, arbitration, conditions performed, ${ }^{21}$ infancy or some other fact which precluded the plaintiff from maintaining his action. ${ }^{22} \mathrm{He}$ could also put in a plea in justification, as, in actions of assault and battery, selfdefense or defense of freehold; ${ }^{23}$ in trespass, that the defendant did the act complained of by virtue of some office which warranted him to do it; or, in an action of slander, that the plaintiff really was as bad a man as the defendant said he was. Finally, a defendant might plead the statute of limitations or some other statutory defense. ${ }^{24}$

The response to a special plea by a defendant was a replication by the plaintiff, traversing or confessing and avoiding the special plea. That could be followed by a rejoinder by the defendant, followed, in turn, by a surrejoinder, a rebutter, and a surrebutter. ${ }^{25}$ A number of technical rules made special pleading a very refined and difficult art. First, a plea was required to be single - that is, to contain only one factual allegation; moreover, a party could set forth only one plea, unless he obtained the court's permission to plead double. Second, a party's plea had to answer his opponent's allegations in every material point. A plea also had to be direct, positive and nonargumentative, certain as to time, place and persons, capable of trial, and properly averred in the common form - "and this he is ready to verify." rule was that the defendant could not put in a special plea which amounted merely to a denial of all or part of the plaintiff's. charge, but had to advance some new fact not mentioned in the declaration. In a writ of assumpsit, for example, where a plaintiff alleged nonpayment or nonperformance by the defendant as one of several essential parts of his cause of action, the defendant could not, in turn, plead payment or performance, ${ }^{27}$ for that plea

Library, Cambridge, Mass.). For examples of special pleading during the first decade after the Revolution, see Trear v. Bacon, [Oct. 1788] Berk. S.J.C. 16; Murray v. Farley, [Nov. 1787] Essex S.J.C. 302; Allen v. Bruce, [May 1787] Worc. S.J.C. 96; Clark v. Holmes, [Nov. 1786] Msex. S.J.C. 424; Sexton v. Parker, [Nov. 1785] Hamp. S.J.C. 161; Commonwealth v. Raymond, [Apr. 1785] Msex. S.J.C. 78; Commonwealth v. Otis, [Mar. 1785] Suff. S.J.C. 1; Peters v. Wilkins, [June 1783] Essex S.J.C. 115.

${ }^{21}$ See Sacket v. Sacket, [Nov. 1771] Hamp. C.P. 106.

${ }^{22}$ See Prouty v. Bryant, [Dec. 1769] Ply. C.P. 25 (plea in debt on administration bond that arbitrators made no award); Phelps v. Cotton, [Aug. 1762] Hamp. C.P. 7 (plea that defendant never warranted primary obligor's ability to pay).

${ }^{23}$ See Allen v. Spooner, [June 1772] Worc. C.P. 397, appeal dismissed, [May 1773] Worc. Super. Ct. 33.

${ }^{24}$ See genetally 3 W. Blackstone, COMMENTARIES *306-13.

${ }^{25} I d * 309-10$.

${ }^{26} I d * 308$.

${ }^{27} S_{e e}$ Lapham v. Corving, [July 1766] Ply. C.P. 193; Hyland v. Clap, [July 1763] Ply. C.P. 378; Partridge v. Hinds, [May 1761] Hamp. C.P. 209. Cf. Stiles v. Leete, [Nov. 1764] Hamp. C.P. 26 (plea that defendant never signed note rejected). 
merely denied an element in the plaintiff's claim and advanced no new fact. The defendant could, however, plead payment by some specified means, ${ }^{28}$ or performance of his contract in some other specific manner, ${ }^{29}$ for such pleas would add new facts and not merely negate facts already pleaded by the plaintiff.

It was only in cases involving title to land that the rules of common law pleading had been somewhat modified by the time of the Revolution. Although the court records contain occasional references even to such obscure writs as novel disseisin, ${ }^{30}$ the ancient English actions such as entry, ejectment, formedon and others had, in general, been embraced in colonial Massachusetts within a single generic form of action variously called a plea of ejectment, a plea of entry, or, more simply and more frequently, a plea of land, which avoided ancient technicalities and resulted in a trial like that in any other civil suit. ${ }^{31}$ In a plea of land, a plaintiff was required to allege the nature of the estate of which either he or the person through whom he claimed the land had been seised ${ }^{32}$ within thirty years prior to the commencement of his suit. ${ }^{33}$ The proper general denial was that the defendant was not guilty or that he did not disseize the plaintiff. If a defendant entered an erroneous plea, such as never promised, judgment would be entered for the plaintiff. A defendant also had the option of pleading specially.

In addition to the generic plea of land, the only other writ in frequent use in litigating title to real property was the writ of

${ }^{28}$ See Crowfoot v. Percey, [Sept. 1763] Berk. C.P. 265.

${ }^{29}$ See Talmadge v. Strong, [Sept. 1769] Berk. C.P. 299, appeal dismissed, [Sept. 1769] Hamp. Super. Ct. 144.

${ }^{30}$ See Ingersoll v. Sikes, [Sept. 1762] Hamp. Super. Ct. 417 (mention made of prior writ of novel disseisin).

${ }^{31}$ See A. STEARNS, supra note 8, at 507-08; 1 LEGAL PAPERS, supra note 4, at 261.

${ }^{32}$ See Stoddard v. Goodrich, [Apr. 1773] Hamp. Super. Ct. 39; Hills v. Brown, [Oct. 1771] Bris. Super. Ct. 166; Wilson v. Linton, [Oct. 1766] Bris. Super. Ct. 148; Rochester Proprietors v. Hammond, Quincy 154 (1765); Ruggles v. Barrows, [May 1764] Ply. Super. Ct. 238. Bare title in the plaintiff was insufficient to make out an allegation of seisin. A plaintiff also had to allege that he was in possession of the land, see Powers v. Powers, [Dec. 1776] Worc. C.P. 457 (abated for failure to allege possession in addition to bare title), or that he was taking the profits thereof. See Moor v. Spencer, [Feb. 1769] Berk. C.P. 270 (writ abated for failure to allege taking of profits). See also Spaulding v. Green, [Oct. 1771] Msex. Super. Ct. 183 (writ containing allegation of taking profits). Not all writs, however, contained this allegation. See Warren v. Apthorp, [Feb. 1772] Suff. Super. Ct. 4.

${ }^{33}$ On the 30-year limitation period, see Stoddard v. Goodrich, [Apr. 1773] Hamp. Super. Ct. 39; Lindale v. Cudworth, [Sept. 1760] Bris. C.P. 410. In addition to his allegation of seisin, a plaintiff also had to describe by metes and bounds the close to which title was being litigated. See Rochester Proprietors v. Hammond, Quincy 159 (1765); Ruggles v. Barrows, [May 1764] Ply. Super. Ct. 238; French v. Cobb, (Bris. Super. Ct. 1763), in 1 R. Paine, Minutes of Trials \& LaW Cases (mss. in Mass. Hist. Soc., Boston, Mass.); King v. Averill, [Sept. 1767] Berk. C.P. 560. 
trespass quare clausum fregit. ${ }^{34}$ As in the plea of land, a plaintiff in trespass had to allege that the land in question was "the plaintiff"s close,"35 an allegation which superficially resembled the allegation of seisin in a plea of land. However, the allegation that the land was the plaintiff's close, unlike the allegation of seisin, did not, upon a defensive plea of the general issue, put seisin in issue. That is, if a defendant pleaded the general issue of not guilty, a judgment upon a writ of trespass would not determine seisin of the land and would not be res judicata in a subsequent suit between the same parties for that land. A defendant could, however, put seisin in issue, if he wished, by pleading, in lieu of the general issue, that the land was "his own proper soil and freehold." A judgment upon that plea would have an effect similar to the effect of a judgment upon the generic plea of land.

${ }^{34}$ In addition to trespass quare clausum fregit trespass was frequently used in 2 other forms in pre-Revolutionary Massachusetts - trespass to the person and trespass de bonis asportatis. Trespass to the person lay for assaults, see King v. Stewart (1773-1774), in 1 LEGAL PAPERS, supra note 4, at 106; Gray v. Pitts (1771), in id. 157; Gill v. Mein (1768-1769), in id. 151; for wrongfully imprisoning the plaintiff "against the Custom of England and this province," Hendricks v. Ashley, [Sept. 1772] Hamp. Super. Ct. 139, even if the imprisonment occurred pursuant to legal process, see Martin v. Welch, [Aug. 1763] Suff. Super. Ct. 112; Perkins v. White, [Nov. 1767] Hamp. C.P. 207; and for having sexual intercourse with the plaintiff's wife. See Dougherty v. Little, [May 1768] Msex. Super. Ct. 163; Staple v. Hammet, [June 1763] York Super. Ct. 70. Cf. Fairbanks v. Morey, [June 1760] Bris. C.P. 374, affd [Oct. 1761] Bris. Super. Ct. 265 (abduction of plaintiff's wife, but no allegation of intercourse). Trespass de bonis asportatis lay for taking money, see Burham v. Mugford (1770-1771), in 1 LEGAL PAPERS, supra note 4, at 149, or valuable documents belonging to the plaintiff, see Bradford v. Crowningshield, [June 1763] Essex Super. Ct. 59; for taking or wounding the plaintiff's animals, see Wise v. Hight, [June 1767] York Super. Ct. 278; Wentworth v. Willum, [July 1765] York Super. Ct. 216; for taking the plaintiff's ship, see Bailey v. Williams, [June 1769] Cumb. Super. Ct. 83; Treat v. Preble, [Oct. 1764] Bris. Super. Ct. 107, modified [Aug. 1765] Suff. Super. Ct. 230; and for destoying the plaintiff's fishing net, see Buck v. Runnels, [Oct. 1763] Essex Super. Ct. 200. In order to bring any writ of trespass, a plaintiff had to prove that the defendant's use of "force and arms," Briggs v. Foster, [Mar. 1773] Bris. C.P. 10, was "against the peace of his Present Majesty." Ingersoll v.Johns, [Sept. 1769] Berk. C.P. 398. It was not, however, necessary for the plaintiff to prove any actual injury in order to recover damages. Cf. Gibbs v. Higgins, [Aug. 1763] Hamp. C.P. 134 (sustaining declaration which set forth injuries only by way of recital instead of by positive averment). He could recover merely for being "robb'd and deprived of that peace, Satisfaction \& Security [to] which every one of the liege Subjects had a right \&c.", Howell v. Pearson, [June 1767] Cumb. Super. Ct. 270, and for his "disgrace." Tyng v. Henshaw, [Aug. 1761] Suff. Super. Ct. 299. Accord, Martin v. Welch, [Aug. 1763] Suff. Super. Ct. 112. A plaintiff could also recover in trespass for consequential, as distinguished from immediate, damages; damages were awarded, for example, for loss of wages due to injuries sustained from an assault, see Spooner v. Allen, [Apr. 1773] Worc. Super. Ct. 33; for the loss of a lawsuit as a result of the defendant's theft of the plaintiff's documents, see Bradford v. Crowingshield, [June 1763] Essex Super. Ct. 59; or for profits from a voyage lost as a result of the defendant's wrongful seizure of the plaintiffs ship. See Bailey v. Williams, [June 1769] Cumb. Super. Ct. 83; Treat v. Preble, [Oct. 1764] Bris. Super. Ct. 107, modified, [Aug. 1765] Suff. Super. Ct. 230; Winslow v. Capen, [Aug. 1762] Suff. Super. Ct. 391 .

35 John Adams' Pleadings Book, in 1 LEgal PAPERS, supra note 4, at 84-85; T. PARSONS, PRECEDENTS No. 71 (mss. in Harvard Law School Library, Cambridge, Mass.). As in the 
It would determine who was seised of the land, ${ }^{36}$ although a plaintiff in trespass could recover only damages for interference with his seisin and not, as in a plea of land, the land itself. ${ }^{37}$

After a plaintiff had selected the correct writ, he was required to have it served on the defendant. Service in a civil action could be accomplished at the plaintiff's option either by a summons or by a capias, or, under special circumstances, by other means ordered by the court. ${ }^{38}$ When a summons was used, a proper officer was simply commanded to summon the defendant, if found within his precinct, to appear at a specified term of the Court of Common Pleas for the appropriate county ${ }^{39}$ In the case of a capias, the officer was directed to attach the goods or estate of the defendant and for want thereof to take his body, if found in his precinct. ${ }^{40}$

plea of land, a plaintiff in trespass also had to describe the close by metes and bounds. See Fowle v. Wyman, Quincy 336 (1773); Foster v. Bradford, [Dec. 1767] Ply. C.P. 355; Sartell v. Parkhurst, [Apr. 1765] Msex. Super. Ct. 159; Bagley v. Ring, [July 1763] Essex C.P. 250. See also Ingersoll v. Hamlin, [Sept. 1769] Berk. C.P. 400 (writ abated for alleging that trespass occurred at 2 different places).

${ }_{36}$ See Jordan v. Miller, [June 1772] Cumb. Super. Ct. 156; Bowdoin v. Branch, [June 1770] Cumb. Super. Ct. 128; Bowdoin v. Springer, [June 1769] Cumb. Super. Ct. 87; Case v. Ingersoll, [Apr. 1764] Berk. C.P. 367.

${ }^{37}$ The execution that issued upon a writ of trespass to which a defendant had pleaded proper soil and freehold gave only money damages and did not put the plaintiff back in seisin of the land. See cases cited note 36 supra.

${ }^{38}$ See Bryant v. Inhabitants of Chesterfield, [Nov. 1768] Hamp. G.S. 104. A plaintiff could elect the means by which he wanted process served, but once he had made his election, service had to be by that means. A suit commenced by a capias, for example, would be dismissed if the officer making the service could find neither the defendant's estate nor his body, see Rogers v. Whitehand, [Dec. 1764] Essex C.P. 428, or if, instead of arresting the defendant, the officer merely summoned him and took security for his appearance. See Mansis v. Butters, [Dec. 1771] Essex C.P. Files. Cf. Barnes v. Greenleaf, Quincy 41 (1763). Service by capias was also insufficient if the officer attached real instead of personal property. See Sargent v. Bishop, [Dec. 1768] Essex C.P. Files. An action against an executor could not, of course, be commenced by a capias directing attachment of the fiduciary's personal estate or body. See Sprague v. Wing, [Oct. 1769] Ply. C.P. 15. Service by summons, on the other hand, would be defective if the summons itself were defective in that it failed to state the plaintiff's cause of action, see Gilbert v. Ulitt, [Oct. 1763] Worc. C.P. 213; Newcomb v. Newland, [June 1763] Bris. C.P. 59; and the amount of damages demanded, see Gilbert v. Ulitt, [Oct. 1763] Worc. C.P. 213; or in that it was not duly authenticated by the court. See Cheney v. Child, [Oct. 1763] Worc. C.P. 210. A misnomer, however, would not invalidate a summons. See Ingales v. Hill, [Sept. 1764] Bris. C.P. 154, appeal dismissed, [Oct. 1764] Bris. Super. Ct. 64. Service by summons would also be defective if a valid summons were not properly served. Proper service required that the summons be left with the defendant at his residence or last usual place of abode. See Story v. Sawyer, [Mar. 1769] Essex C.P. Files; Page v. Nurse, [May 1763] Worc. C.P. 127. It was not sufficient for the officer merely to read the summons to the defendant. See Robinson v. Geyer, [Oct. 1772] Suff. C.P. Files; Stow v. Wyman, [May 1770] Msex. C.P. Files.

${ }^{39}$ See, e.g., Potamia v. Gould, [Nov. 1767] Msex. C.P. Files; Boucher v. Stearns, [Dec. 1760] Msex. C.P. Files; Fohn Adams' Pleadings Book, in 1 LEGAL PAPERS, supra note 4, at $34,36,37,42,43,51,58,60,62,65,80$.

${ }^{40}$ See Hedden v. Noyes, [Sept. 1770] Essex C.P. Files; Farrow v. Wilson, [May 1765] 
Three basic rules regulated the service of all process, both summons and capias. First, process was required to be served by an officer. ${ }^{41}$ Second, the writ had to be served by the particular officer to whom it was directed. ${ }^{42}$ Finally, service on a defendant had to be accomplished at least fourteen days before the court sat ${ }^{43}$ and had to notify the defendant of the time at which court would meet. ${ }^{44}$

A plaintiff also had to be certain that all parties who ought to

Msex. C.P. Files; Fohn Adams' Pleadings Book, in 1 LEg AL PAPERS, supra note 4, at 39, 41, $45,47,48-49,55,59,63,68,79,81,84,85$. An officer could not be commanded to attach goods without also being commanded to take the defendant's body if no goods could be found. See Eaton v. Hart, [Mar. 1766] Essex C.P. 554. A thorough examination of fohn Adams' Pleadings Book, in 1 LEGAL PAPERS, supra note 4, at 31-86 and the pleadings book of Theophilus Parsons, mss. in Harvard Law School Library, Cambridge, Mass., reveals that a plaintiff's attorney had the option of using a summons or a capias in all writs. See [1699] Mass. Laws, ch. 2. See also Hanlon v. Thayer, Quincy 99 n.2 (1764). Of 23 actions of debt recorded in the books, for example, 12 were begun by a capias and 11 by a summons; of 63 actions of case, 51 by capias and 12 by summons; of 10 actions of trespass, 6 by capias and 4 by summons; and of 23 actions for the recovery of land, 1 by capias and 22 by summons. All 7 writs of covenant in the Parsons book were begun by capias, while the 3 actions of account in the 2 books were begun by summons. In actions of case, one can find, in addition to practice by the bar, judicial statements and holdings sanctioning service either by attachment alone, see Barlett v. Kennedy, [Mar. 1767] Essex C.P. 82 (overruling plea that service by summons without attachment defective), or by summons alone. See Leonard v. Stetson, [May 1765] Ply. Super. Ct. 34 (overruling plea that service by attachment without summons defective); Blanchard v. Torney, [Dec. 1765] Msex. C.P. 115 (noting that service upon defaulting defendant was of the sort "where Estate only was attached").

${ }^{41}$ See Holden v. Holman, [Sept. 1762] Berk. C.P. 132. Usually that officer was a sheriff or his deputy, but in suits under 10 pounds, a plaintiff could direct that service be made by a town constable instead. See Bragg v. Norwood, [Mar. 1771] Essex C.P. 94; Barry v. Mason, [Sept. 1770] Bris. C.P. 274, aff d, [Oct. 1770] Bris. Super. Ct. 199; Dike v. Alexander, [Sept. 1766] Essex C.P. 30, rev'd on default, [Nov. 1766] Essex Super. Ct. 178; Brewer v. Brown, [Feb. 1764] Worc. C.P. 294. If a sheriff or deputy was party to a suit, service was required to be made by a constable, but see Dewey v. Sackett, [Apr. 1762] Berk. C.P. 99, or, if the suit was for more than 10 pounds, by a county coroner. See Nickols v. Wait, [Sept. 1764] Worc. Super. Ct. 6; Rowlee v. Sanford, [Feb. 1769] Berk. C.P. 221, reo'd on defaulh [Sept. 1769] Hamp. Super. Ct. 141. See also Briggs v. Bennett, [May 1765] Bris. C.P. 221 (writ abated since directed to improper officer). But a deputy sheriff who was a resident in a town which was a party to an action could serve process. See Hopkins v. Inhabitants of Great Barrington, [Sept. 1769] Berk. C.P. 311.

${ }^{42} \AA$ writ directed to one sheriff, for example, could not be served by another. See Willson v. Proprietors of Pejepscott, [June 1767] Cumb. Super. Ct. 269; Williams v. Fairfield, [July 1769] Essex C.P. 432. A writ directed to a sheriff could not be served by a constable. See Reed v. Purrinton, [Oct. 1771] Ply. C.P. 316; Norwood v. Pulcifer, [Sept. 1768] Essex C.P. 325. And a writ directed to a coroner could not be served by a deputy sheriff. SeeJennison v. Stone, Suff. Files No. 152271 (Worc. Super. Ct. 1767); Whitney v. Adams, [Feb. 1769] Berk. C.P. 234. A writ could, however, be directed to more than 1 officer if there were need to do so; such a need would arise, for example, in cases involving joint defendants living in different counties. See Williams v. Fosse, [Aug. 1765] Bris. C.P. 280.

${ }^{43}$ See [1699] Mass. Laws ch. 3, $\$ 4$. See generally 1 LEGAL PAPERS, supra note 4, at lxviii.

${ }^{44}$ See Harwood v. Cragin, [Mar. 1774] Berk. C.P. 300; Hodges v. Gilmore, [Oct. 1765] Bris. Super. Ct. 310; Ely v. Burbank, [May 1767] Hamp. C.P. 95; Dole v. Tollansbee, [Sept. 1764] Essex C.P. 402. But see Fowler v. Barber, [May 1762] Hamp. C.P. 307 (writ not abated if proper term of court is stated therein, but that term is slightly misdated). 
be joined in litigation were joined and that parties who ought not be joined were not. Rules on this subject were quite technical. ${ }^{4.5}$ Joint obligors and joint promissors, for example, both had to be joined in a suit on their promise and process had to be served on both of them. ${ }^{46}$ Joint promissees also had to be joined, although a husband was not required to join his wife if a promise had been made jointly to her, ${ }^{47}$ for a wife was "neither privy to the Contract nor the Person to whom the Money is to be paid."48 A wife, on the other hand, would have to join her husband, ${ }^{49}$ even if she were a white woman and he were a Negro slave. ${ }^{50}$ Tenants in common were also required to join in land pleas and in personal actions such as trespass, assumpsit and nuisance. ${ }^{51}$ Joint bailors, on the other hand, did not have to sue their bailee together, ${ }^{52}$ and agents were not required to be joined in suits against their principals. ${ }^{53} \mathrm{~A}$ plaintiff also had to be certain to bring any executor or administrator before the court in cases of claims for or against a decedent. ${ }^{54}$

The most technical of all the pleading rules required the parties to litigation to be precisely identified. Pursuant to this requirement, civil and criminal actions were dismissed when there was no person who had the name and description given the defendant in the writ. ${ }^{55}$ Civil and criminal actions were similarly dismissed for failing to state the full name of a party to the writ ${ }^{56}$

\footnotetext{
${ }^{45} \mathrm{~A}$ claim of improper joinder could be raised only by a plea in abatement, and failure to make such timely objection constituted a waiver thereof. See Keep v. Prescott, Cushing 7 (1773).

${ }^{46}$ See Banks v. Jordan, [June 1767] Cumb. Super. Ct. 271; Ingersoll v. Baker, [May 1773] Berk. C.P. 549; Ingersoll v. Read, [Sept. 1766] Berk. C.P. 364. Principal and surety could be sued as joint promisors. See Porter v. White, [Mar. 1763] Essex C.P. 465. Coexecutors and coadministrators were required to be joined. See Rogers v. Orne, [Mar. 1764] Essex C.P. 325. It was not necessary, however, that the goods of all promisors be attached. See Tripp v. Durfey, [Oct. 1761] Bris. Super. Ct. 261 (rev'g on undetermined grounds).

${ }^{47}$ See Kent v. Pratt, [Aug. 1764] Hamp. C.P. 262, appeal dismissed, [Sept. 1764] Hamp. Super. Ct. 41.

48 Fohn Adams' Commonplace Book, in 1 LEGAL PAPERS, supra note 4, at 18.

${ }^{49}$ See Daniels v. Bowin, [Sept. 1764] Worc. Super. Ct. 4.

${ }^{50}$ See Caesar v. Taylor (1771-1772), in 2 LEGAL PAPERS, supra note 4, at 59,61.

${ }^{51}$ See Prescott v. Keep (1771-1776), in 1 LEGAL PAPERS, supra note 4, at 266, 268; Pennel v. Small, [June 1764] York Super. Ct. 271; Marston v. Coombs, [July 1772] Essex C.P. Files; Fowler v. Sacket, [Aug. 1766] Hamp. C.P. 227. If one tenant in common died during the pendency of the action, the action survived to the remaining tenants. See Prescott v. Priest, Cushing 4 (1773).

${ }^{52}$ See Choate v. Severy, [Mar. 176.5] Essex C.P. 442.

${ }^{53}$ See Perkins v. Goldthwait, [Nov. 1766] Hamp. C.P. 8.

${ }^{54}$ See Graves v. King, [Sept. 1768] Berk. C.P. 82.

${ }^{55}$ See Hart v. Eaton, [Nov. 1766] Essex Super. Ct. 175; Rex v. Sprague, [May 1768] Hamp. G.S. 79.

${ }^{56}$ See Flint v. Ingersoll, [Aug. 1763] Hamp. C.P. 126. Contra, Morey v. Richardson, [Sept. 1762] Bris. C.P. 559.
} 
or for misspelling or otherwise misstating a party's name ${ }^{57}$ either his Christian name ${ }^{58}$ or his surname. ${ }^{59}$ An even greater need for certainty in naming parties occurred in suits in which corporate parties were involved, and here too writs were abated for misnomers. ${ }^{60}$

In addition to requiring that a plaintiff give all parties their proper names, the law further required him to state correctly, without any misspelling, the town and county in which each party resided. ${ }^{61}$ This requirement that a writ state the residence of the parties served not only to identify them, but also to insure that service of process was made upon a defendant at his proper residence. ${ }^{62}$ Moreover, since venue in transitory actions depended upon at least one of the parties being a resident of the county in which the suit was brought, the rule also served to insure proper venue. ${ }^{63}$

${ }^{57}$ See Wheeler v. Cole, [May 1767] Bris. C.P. 451. But see King v. Collins, [Mar. 1766] Essex G.S. 80 (abatement for misnomer denied in criminal case). The Massachusetts rules were substantially the same as the English rules on misnomers. See generally H. Stephen, A Treatise on the Principles of Pleadings in Civil ACtions 319 (1824).

${ }^{58}$ See Atwater v. Merwin, [May 1774] Berk. C.P. 427.

${ }^{59}$ See Parsons v. Waunchuauncet, [May 1773] Berk. C.P. 546; Mace v. Rogers, [Aug. 1767] Hamp. C.P. 134; Aldridge v. Prat, [May 1767] Bris. C.P. 465; Cullar v. Wood, [Nov. 1764] Worc. C.P. 409.

${ }^{60}$ Housatonnock Proprietors v. Williams, [Sept. 1771] Hamp. Super. Ct. 155, aff'g [Sept. 1771] Berk. C.P. 284.

Sil See Ballard v. McLean, Quincy 106 (1764) (town misstated); Watson v. Ulley, [Sept. 1761] Hamp. Super. Ct. 254 (county misstated); Brown v. Will, [May 1760] Ply. Super. Ct. 34 (town misstated); Seymour v. Way, [Sept. 1770] Berk. C.P. 24 (town misnamed); Younglove v. Fonda, [Sept. 1770] Berk. C.P. 615 (county not stated); Bliss v. Mason, [Aug. 1770] Hamp. C.P. 533 (county misstated); Griffin v. Hilyer, [Feb. 1770] Berk. C.P., rev'd on defaulh [Sept. 1770] Hamp. Super. Ct. 181 (town misstated); Perrigo v. Howard, [Oct. 1769] Ply. C.P. 13 (town misstated); Hickok v. Spoor, [Sept. 1769] Berk. C.P. 348 (town misstated); Warner v. Ramsdell, [Aug. 1769] Hamp. C.P. 440 (residence misstated); Russell v. Diamond, [May 1769] Msex. C.P. Files (town and county not stated); Latham v. Turner, [Dec. 1766] Ply. C.P. 231, rev'd on defaulh [May 1767] Ply. Super. Ct. 236 (town misspelled); Blankinship v. Holmes, [Oct. 1766] Ply. C.P. 218 (town misstated); Burghardt v. North, [Sept. 1766] Berk. C.P. 282 (county not stated); Fonda v. Fitch, [Sept. 1766] Berk. C.P. 361 (town misstated); Cobb v. Soper, [Aug. 1765] Bris. C.P. 285 (town misstated); Briggs v. Bennett, [May 1765] Bris. C.P. 221 (county not stated and town misstated); Fellows v. Campbell, [May 1764] Worc. C.P. 338 (county not stated); Duboys v. Gelusiah, [Sept. 1763] Berk. C.P. 295 (county misspelled); Flint v. Ingersoll, [Aug. 1763] Hamp. C.P. 126 (town abbreviated); Lee v. Lee, [July 1763] Essex C.P. 249 (county not stated); Fuller v. Clark, [Dec. 1762] Msex. C.P. 380 (town misstated); Fosburg v. Fuller, [Sept. 1762] Berk. C.P. 182, appeal dismissed, [Sept. 1763] Hamp. Super. Ct. 169 (town misstated); Roberts v. Church, [Apr. 1762] Berk. C.P. 84 (town misspelled). But see Jackson v. Munro, [Nov. 1766] Bris. C.P. 427 (abatement for misspelling province denied). The English rule, again, was the same as that in Massachusetts. See Turvil v. Aynsworth, 2 Ld. Raym. 1515, 92 Eng. Rep. 483 [K.B. (1727)].

${ }^{62}$ See Levi v. Page, [July 1772] Essex C.P. 311 (waiver upon consent of plea in abatement that defendant's residence was misstated with result that he was not properly served).

${ }^{63}$ See Cobb v. Soper, [Aug. 1765] Bris. C.P. 285 (dismissal for improper venue). On 
In order to provide further identification of the parties, the plaintiff was also required to state correctly the addition, that is, the occupation or social rank, of both plaintiff ${ }^{64}$ and defendant. ${ }^{65}$ Failure to do so was ground for abatement of a writ, and, in criminal cases, for dismissal of an indictment. ${ }^{66}$ More suits were abated or dismissed for improper additions than on any other ground. Much elaborate learning existed on the subject of additions: one finds the bench and bar of the Superior Court debating, for instance, whether the description of blacksmith includes a nailor ${ }^{67}$ and whether a militia captain is a gentleman by way of commission, reputation or courtesy. ${ }^{68}$ In one case, a writ was even abated because the plaintiff's testator had been given an improper addition. ${ }^{69}$

As noted earlier, many pleading rules were carried to such extremes that they ceased to serve any rational function. For example, a frequently invoked rule provided that a defendant

the requirement that at least one party in a transitory action be a resident of the county in which suit was brought, see Ward v. Carter, [Sept. 1771] Msex. C.P. 122. See also W. Nelson, The Americanization of the Common Law During the Revolutionary Era, April, 1971 , at 17 n.45 (unpublished Ph.D. dissertation on file in Widener Library, Harvard University).

${ }^{64}$ See Wise v. Hight, [June 1767] York Super. Ct. 278 (plaintiff should be called gentleman, not yeoman); Homan v. Tucker, [Dec. 1766] Essex C.P. 56 (no allegation that plaintiff an administrator); Willmot v. Gray, [Sept. 1763] Berk. C.P. 300 (plaintiff should be called yeoman, not gentleman); Phelps v. Kellogg, [May 1763] Hamp. C.P. 95 (plaintiff should be called gentleman, not esquire); Sumner v. Dudley, [Apr. 1762] Berk. C.P. 90 (plaintiff should be called yeoman, not gentleman).

${ }_{65}^{65}$ Bromfield v. Lovejoy, Quincy 237 (1767) (defendant should be called gentleman, not yeoman); Pickard v. Lowell, [Nov. 1767] Essex Super. Ct. 87 (defendant should be called tanner, not blacksmith); Pell v. Fellows, [Sept. 1770] Berk. C.P. 618 (defendant should be called gentleman, not yeoman); Wheelock v. Goodspeed, [Aug. 1769] Worc. C.P. 525 (defendant should be called yeoman, not gentleman); Whiting v. Naunaumphtaunk, [Feb. 1769] Berk. C.P. 228 (defendant should be called gentleman, not yeoman); Rotch v. Brock, [Mar. 1768] Nan. C.P. 236 (defendant should be called mariner, not gentleman); Ames v. Lathrop, [Jan. 1767] Suff. C.P. Files (defendant should be called blacksmith, not husbandman); Storer v. Twiss, [Dec. 1766] Essex C.P. 67 (defendant should be called administratrix, not executrix); Hickok v̀. Sheldon, [Sept. 1765] Berk. C.P. 184 (defendant should be called gentleman, not yeoman); Lee v. Martin, [Apr. 1765] Berk. C.P. 70 (defendant's addition not stated); Eames v. Hayward, [May 1764] Msex. C.P. 579, appeal dismissed, [Apr. 1765] Msex. Super. Ct. 163 (defendant should be called yeoman, not gentleman); Cheney v. Child, [Aug. 1763] Worc. C.P. 55 (defendant should be called laborer, not yeoman); Burbank v. Worster, [Aug. 1761] Hamp. C.P. 239 (defendant should be called spinster, not widow); Bumpas v. Whitten, [Oct. 1760] Ply. C.P. 55 (defendant should be called laborer, not yeoman); Walker v. Colby, [May 1760] Worc. C.P. 289 (defendant should be called husbandman, not housewright). The rules concerning additions were applied even more strictly in England, where "names of dignity" as well as additions had to be written in proper form. See H. STEPHEN, A TREATISE ON THE PRINCIPLES OF PleAdiNG IN CiVIL ACTIONS 319-21 (1824).

${ }^{66}{ }_{\text {See }}$ King v. Miller, [Mar. 1774] Essex G.S. 339 (defendant should be called gentleman, not yeoman). For civil cases, see notes 64-65 supra.

${ }^{67}$ See Blower v. Campbell, Quincy 8 (1763).

${ }^{68}$ See Bromfield v. Lovejoy, Quincy 237 (1767).

${ }^{69}$ See Whiting v. Whiting, [Sept. 1767] Berk. C.P. 4 (plaintiff's testator should be called esquire, not gentleman). 
could obtain abatement of a writ if he had the same name as his father and was not called "junior," as long as both father and son were of the same town. ${ }^{70}$ Similarly, a defendant who was mistakenly called "junior" could obtain abatement." Munson $v$. Clark, $^{72}$ a paternity suit, is illustrative. The rule in paternity was that a mother could not obtain support for her illegitimate child unless she had accused the defendant of being its father during the time of her "travail." "I3 In Munson, the mother had accused the defendant of being the father, but since she had failed to call him "junior" during the course of her accusation, the court dismissed her suit. Munson, of course, is an extreme case, which, however, shows that at least some cases turned on such useless technicalities.

A plaintiff finally had to surmount several other procedural obstacles. One was the requirement that his writ be endorsed either by himself or by his attorney, ${ }^{74}$ the endorser being liable for costs in the event the plaintiff lost his action. ${ }^{75}$ Another requirement was that the writ bear the teste of the appropriate

${ }^{70}$ See Zuill v. Bradley, Quincy 6 (1762); Goodspeed v. Gay, [May 1763] Barns. Super. Ct. 47; Trefrey v. Thaxter, [July 1768] Suff. C.P. Files; Fearing v. Pearce, [Apr. 1767] Ply. C.P. 269; Thayer v. Brown, [Aug. 1762] Worc. C.P. 51. In cases in which 2 unrelated persons in the same town had the same name but the plaintiff failed to style one of them "the younger," see Ely v. Smith, [Aug. 1762] Hamp. C.P. 39, or "the second of that name," see Willson v. Luther, Suff. Files No. 145402 (Bris. Super. Ct. 1768); Thomson v. Woolcot, Suff. Files No. 152195 (Worc. Super. Ct. 1766); the possibility of confusion was as great as in cases involving identically named fathers and sons. The courts, however, were never clear as to whether the misnomer rule applied in such cases. In 2 cases they held it did, see Gifford v. Butter, [Dec. 1772] Bris. C.P. 402; Leonard v. Porter, [May 1767] Bris. C.P. 455, but in others they ignored the purpose of the rule, applying custom rather narrowly, simply because it was custom, and refused to extend it to an analogous case. See Ballard v. McLean, Quincy 106 (1764). See also Willson v. Luther, Suff. Files No. 145402 (Bris. Super. Ct. 1768); Thomson v. Woolcot, Suff. Files No. 152195 (Worc. Super. Ct. 1766); Ely v. Smith, [Aug. 1762] Hamp. C.P. 39. Likewise, a court refused to abate a writ in which a plaintiff gave a defendant an improper alias. See Wheeler v. Cole, Suff. Files No. 145315 (Bris. Super. Ct. 1767). Here too a potential for confusion existed, but the court declined to look at whatever underlying rationale the misnomer rule may have had.

${ }^{71}$ See Willson v. Luther, [Aug. 1767] Bris. C.P. 498; Deboys v. Bement, [Sept. 1763] Berk. C.P. 294. Cf. Leonard v. Porter, [May 1767] Bris. C.P. 455 (abated for calling defendant "the second" when he was in fact "the third").

72 [May 1771] Hamp. G.S. 174.

${ }^{73}$ See Thyot v. Whitman, [July 1770] Essex G.S. 201; Act of Nov. 1, 1692, ch. 18, $\$ 5$, 1 Mass. Acts and Resolutions 52, cited in 1 LEGAL PAPERS, supra note 4, at 320.

${ }^{74}$ See Waldo v. Haskell, [July 1765] York Super. Ct. 92; Daniels v. Smith, [Aug. 1764] Suff. Super. Ct. 110; Dodge v. Manning, [Sept. 1767] Essex C.P. 175; How v. Manning, [Mar. 1766] Essex C.P. 587; Eday v. Phelps, [Apr. 1764] Berk. C.P. 377; Green v. Jones, [May 1762] Worc. C.P. 432. An endorsement by the defendant's rather than the plaintiff's attorney was insufficient. See Blood v. Blood, [Mar. 1762] Msex. C.P. 278. In replevin, a plaintiff also had to give a bond to prosecute his action. See Davis v. Smith, [Nov. 1761] Worc. C.P. 378.

${ }^{75}$ See Ingraham v. Cook, Quincy 4, 5 (1762) (dictum) (new endorser required whenever "it could be made to appear to the Court that there was Danger the present Indorser could not answer Costs"). 
court official-in the case of Common Pleas, the first justice. ${ }^{76} \mathrm{~A}$ writ would also be abated if another writ were already pending on the same cause of action, ${ }^{77}$ and a suit by an administrator would be abated if he failed to produce his letters of administration. ${ }^{78} \mathrm{~A}$ plaintiff was also required to allege damages $^{79}$ and, moreover, to make the allegation in proper form. ${ }^{80}$ Finally, he had to avoid the pitfall of a variance-that is, an inconsistency in his allegations, either within his writ ${ }^{81}$ or between a writ and a subsidiary instrument, such as a bond, ${ }^{82}$ an account, ${ }^{83}$ or a will. ${ }^{84}$

\section{THE DEMAND FOR REFORM IN THE LATE EIGHTEENTH CENTURY: JOINDER, SERVICE OF PROCESS, AND VENUE}

In the 1780's these various rules of pleading and procedure, and the manner in which they were manipulated by lawyers, were frequently attacked, particularly in the agrarian strongholds of western Massachusetts, as oppressive and unduly expensive. To some observers, "judicial proceeding[s]" appeared so "intricate" that their usual outcome was only "to throw an honest man out of three quarters of his property" if he

${ }^{76}$ See Smith v. Moody, [Sept. 1764] Hamp. Super. Ct. 34; Clark v. Moody, [Sept. 1764] Hamp. Super. Ct. 33; Dwight v. Spencer, [Feb. 1760] Hamp. C.P. Files. Cf. Volentine v. Stephens, [Dec. 1764] Bris. C.P. 200 (abated for improper date of teste).

${ }_{77} S_{e e}$ Bacon v. Hayward, [May 1767] Worc. C.P. 192; Brown v. Rowley, [Sept. 1764] Berk. C.P. 472.

${ }^{78}$ See Powell v. Pettit, [Sept. 1760] Hamp. Super. Ct. 128, rev'g [Feb. 1760] Hamp. C.P. Files.

${ }^{79}$ See Hayward v. Lothrop, [Oct. 1768] Bris. Super. Ct. 290; 1 Legal PAPERS, supra note 4 , at 33 n.22.

${ }^{80}$ See Hayward v. Lothrop, [Oct. 1768] Bris. Super. Ct. 290; Gilbert v. Chace, [Dec. 1773] Bris. C.P. 61; Thayer v. Thayer, [May 1762] Worc. C.P. 415, appeal dismissed, [Sept. 1762] Worc. Super. Ct. 412. But see Spencer v. Cooley, [May 1761] Hamp. C.P. Files, appeal dismissed, [Sept. 1761] Hamp. Super. Ct. 258.

${ }^{81}$ See Smith v. Moody, [Sept. 1764] Hamp. Super. Ct. 34 (abated for saying in one part of writ that cattle were "distrained" and in another part that cattle were "detained"); Clark v. Moody, [Sept. 1764] Hamp. Super. Ct. 33 (same); Bowen v. Kelley, [Mar. 1774] Bris. C.P. 76 (abated for variance between writ in account and declaration in case); Rowley v. Sheldon, [Feb. 1770] Berk. C.P. 477 (abated for repugnancy in description of land).

${ }^{82}$ See Paddock v. Pratt, [Oct. 1768] Ply. C.P. 439. But see Gager v. Mattoon, [Nov. 1760] Hamp. C.P. 190, [Feb. 1761] Hamp. C.P. 201, appeal dismissed, [Sept. 1762] Hamp. Super. Ct. 416 (overruling plea alleging variance).

${ }^{83}$ See Cobb v. Barstow, [Dec. 1760] Bris. C.P. 417. Cf. Burnal v. Gwin, [Mar. 1770] Nan. C.P. 252 (abated since no account annexed to writ).

${ }^{84}$ See Ashley v. Ashley, [Feb. 1771] Berk. C.P. 292, appeal dismissed, [Apr. 1771] Hamp. Super. Ct. 90. However, if there was a constructional issue whether a will was consistent with a writ, the will was admitted into evidence for the jury to construe. See Gibbs v. Gibbs, Quincy 251 (1767). 
put his case to law. ${ }^{85}$ Opponents of the common law system contended that "the state of pleading in this Commonwealth [had become such] that an honest man ... [could] not obtain" right and justice "without being obliged to employ a lawyer, at a great expence." 86 "Artful men in England," they explained, "ha[d] so entangled the mode of managing a cause with the nice distinction of special pleas (and ... [the courts in Massachusetts had] unfortunately adopted the pernicious practice) that in short justice ... [ [could] scarcely be obtained unless it be dearly purchased." " "[I]nstead of obtaining justice 'freely,' 'completely,' and 'promptly,' " many litigants saw their "causes ... carried through every tedious labyrinth" ${ }^{\text {" }} 8$ and juries "hindered from coming to a speedy decision of a cause, by the labouring pleadings" of the common law. ${ }^{89}$

Reformers in the 1780's accordingly sought to abandon technical and outmoded pleading forms and have judgments rendered "according to the merits of the case." "[P]leas," it was urged, should "be simple, and the clerk [should be] authorized to write them in short form for each of the parties."91 There existed no "occasion or need ... of all the parade of written pleas, replications, rejoinders, \&c. \&c. in common trials at law," since all that a court needed to know was "the fact, the law, and the equity of the case." ${ }^{.92}$ Then, it was contended, the issue of causes would not "depend upon adroitness of advocates ... [but] upon their intrinsic justice." ${ }^{\text {. S3 }}$ Specifically, the legislature was urged to enact a statute "for pleading the general issue in all cases, and admitting special matter to be given in evidence" thereunder, as a "means of opening more fully the merits of the cause, and being free from necessity of making formal pleas." 94

Dissatisfaction with the expense and technicality of common law procedure culminated during Shays' Rebellion, in which high litigation costs, high taxes and lack of currency were the

${ }^{85}$ B. Austin, Observations on the Pernicious Practice of the Law 3-4 (1794) (originally published in the 1780's under the pseudonym "Honestus") [hereinafter cited as AUSTIN].

${ }^{86}$ Boston Gazette, May 13, 1782, at 1, col. 2.

${ }^{87}$ Id. col. 1 .

${ }^{88}$ AUSTIN, supra note 85, at 29.

89 Id 9.

${ }^{90}$ Letter from James Neale to Robert Treat Paine, June 6,1794 , on file in Massachusetts Historical Society, Boston, Mass.

${ }^{91}$ Boston Gazette, May 13, 1782, at 1, col. 1 .

92 Boston Gazette, May 6, 1782, at 1, col. 3 .

${ }^{93}$ Hubbell v. Hoose, [Feb. 1824] Berk. C.P. 8.

${ }^{94}$ Boston Gazette, May 13, 1782, at 1, col. 2. 
chief complaints. ${ }^{95}$ Prior to that disturbance, however, the courts and the legal profession had begun to take hesitant steps toward reform. The process of reform was a gradual and ambiguous one, and the reasons for it are often unclear. Reform occurred piecemeal, as individual lawyers, either lacking in precise knowledge of common law pleading rules or seeking some strategic advantage in litigation at hand, entered pleas that were not in proper form. Although opposing counsel sometimes waived the informality, the want of form was often called to the court's attention. The courts, however, sensing the validity of reformers' complaints about the undue expense of technical pleading rules and perceiving that reduced adherence to form threatened no tangible interest of the law or the legal profession, ${ }^{96}$ often decided to permit counsel either to ignore or to amend the informality. As various decisions of this sort cumulated over time, the ancient system of common law pleading was destroyed, and new rules of pleading emerged in its place. But, while destruction of the old technical pleading system was, at least in part, a response to conscious awareness of its deficiencies, there is no evidence that men perceived the contours of the new system until, after it had largely come into existence, they began to articulate the reality that confronted them.

The first step was taken quite early, in September 1776, when the Superior Court adopted a rule providing that prior to joinder in demurrer, any plaintiff could "have leave to amend his Writ and declaration upon his paying the Deft. his costs" to the date of the amendment or "agreeing to a Continuance at the Defts. Election." ${ }^{\text {97 }}$ This new rule was not given immediate effect in some of the lower courts, which continued to dismiss cases on technical grounds, ${ }^{98}$ until the legislature provided in 1784 that (1954).

${ }^{95}$ See R. Taylor, Western Massachusetts in the ReVOlution 103-15，128-36

${ }^{96}$ See text accompanying note 4 supra.

${ }^{97}$ Worc. Super. Ct. Rule (1776), copied in note appended to Biscoe v. Gale (Msex. S.J.C. 1789), in F. Dana, Minute Books (mss. in Massachusetts Historical Society, Boston, Mass.) [hereinafter cited as Dana].

${ }^{98}$ See Gage v. Noyes, [Apr. 1784] Essex C.P. 68, plea in abatement withdrawn, [June 1784] Essex S.J.C. 174 (abated for improper addition); Gerrish v. Carr, [Apr. 1782] Essex C.P. 211 (same); Mackintire v. Jones, [Dec. 1781] Worc. C.P. 284 (same); Parks v. Sacket, [Nov. 1783] Hamp. C.P. 93 (abated for improperly describing self as administrator of the "Rights \& Credits" rather than of the "Goods \& Chattels" of decedent and for senseless language in writ and failure to aver date of note); Hammond v. Delano, [Apr. 1783] Ply. C.P. 480 (abated for not pursuing Register). Judicial obstruction of reform was not limited to Massachusetts during this period. Ambitious procedural reform in Georgia was also hindered by the courts. See L. Friedman, A HISTORY OF AMERICAN LAW 129 (1973). 
judicial proceedings should not "be abated, arrested, quashed or reversed for any kind of circumstantial errours [sic] or mistakes . . . nor through defect or want of form only." explicitly confirmed the power of the courts "on motion ... [to] order amendments." 100 The rule and the statute even then had no effect upon the question of misjoinder of parties, ${ }^{101}$ which was deemed "an exception to the merits," at least in contract actions, ${ }^{102}$ but upon other technical questions of pleading its effects were transforming. By the mid-1780's it was clear that misnomers ${ }^{103}$ and errors in additions ${ }^{104}$ were freely amendable; ${ }^{105}$ indeed, there is no record of any suit being dismissed after

${ }^{99}$ Law of Oct. 30, 1784, $\S 14,1$ [1780-1807] Laws of Mass. 207.

${ }^{100} I d$.

${ }^{101}$ Rules on joinder of parties remained exceedingly complex and technical. Some of the basic rules were as follows: In contract actions, joint promisors and joint promisees all had to be joined. See Drury v. Baxter, [Apr. 1825] Suff. C.P. 41; Belcher v. Ward, [Mar. 1825] Worc. C.P. 68, appeal dismissed, [Oct. 1826] Worc. S.J.C. 638; Shaw v. Bottom, [Mar. 1825] Worc. C.P. 19; Allen v. Wing, [Aug. 1816] Ply. C.P. 122 n.31, affd by referees, [Oct. 1816] Ply. S.J.C. 190; Adams v. Savage, [July 1816] Suff. C.P. 240; Kearney v. McMullock, [Sept. 1812] Suff. C.P. 125. This was true even if the plaintiff had no knowledge of the existence of the joint promisor. See Niles v. Prescott, [Sept. 1802] Worc. S.J.C. 157. However, an administrator had to be sued in his representative rather than his personal capacity, see Francis v. Wynn, [July 1782] Essex C.P. 337, appeal dismissed, [June 1783] Essex S.J.C. 119, and therefore an administrator could not join with a surviving promisee to recover on a contract right of the decedent. Smith $v$. Franklin, 1 Mass. 480 (1805); Walker v. Maxwell, 1 Mass. 104, 112-13 (1804). Persons with a subsidiary interest in a contract right could not join with the principal promisee to enforce the right. Grozier v. Atwood, 21 Mass. (4 Pick.) 234 (1826). Cf. Baxter v. Rodman, 20 Mass. (3 Pick.) 435, 438-39 (1826). Joint tortfeasors need not be joined in a single action, see Mitchell v. Keith, [Oct. 1789] Ply. C.P. 405, nor could they be joined if only one of them had actually committed the tort and the other's liability was of a derivative nature. Campbell v. Phelps, 18 Mass. (1 Pick.) 62, 66-68 (1822). Joint victims of a personal tort could not join, since their injuries were of a separate rather than a joint nature. Baker v. Jewell, 6 Mass. 460 (1810) (dictum). Co-owners of property, on the other hand, were required to join in suits brought to recover for tortious damage to the property. See Daniels v. Daniels, 7 Mass. 135 (1810); Derby v. Harraden, [July 1779] Essex C.P. 520. See also Thompson v. Hoskins, 11 Mass. 419 (1814) (misjoinder must be objected to upon plea in abatement). Tenants in common, however, could not join to recover the property itself. See Inhabitants of Rehoboth v. Hunt, 18 Mass. (1 Pick.) 224, 228 (1822). Other joint owners could, but were not required to, join in suits to recover their property. Oxnard v. Proprietors of Kennebeck Purchase, 10 Mass. 179 (1813).Joint guardians could maintain suit together. Shearman v. Akins, 21 Mass. (4 Pick.) 283, 291-92 (1826). Parties who had once been joined could not thereafter be severed for causes such as want of evidence of their joint liability, see Brett v. Proprietors of West Shore, [May 1790] Ply. S.J.C. 103, disability, see Oxnard v. Proprietors of Kennebeck Purchase, 10 Mass. 179 (1813), or death, see Cutts v. Haskins, 11 Mass. 56 (1814). A settlement by a defendant with one of several joint plaintiffs did not, however, preclude the maintenance of suit by the others. Baker v. Jewell, 6 Mass. 460 (1810).

${ }^{102}$ Baker v. Jewell, 6 Mass. 460, 462 (1810).

${ }_{103} S_{e e}$ Sherman v. Proprietors of Connecticut River Bridge, 11 Mass. 338 (1814).

${ }^{104}$ See Kincaid v. Howe, 10 Mass. 203 (1813); Holcomb v. Root, [May 1792] Hamp. C.P. 84. Cf. Atkins v. Sawyer, 18 Mass. (1 Pick.) 351, 353-54 (1823) (dictum) (permitting amendment of judgment rendered "against the administrator" to read "against the goods and estate of the intestate").

${ }^{105}$ See generally S. Howe, Lectures on the Practice of the Courts, 115-16 (mss. in 


\section{4 for a misnomer or an improper addition. ${ }^{106}$ Other technical} errors, such as a mistake in a party's residence, ${ }^{107}$ failure on the part of an infant to bring his suit by a prochein $a m i,{ }^{108}$ failure to have a writ properly attested, ${ }^{109}$ an error in the ad damnum of a writ, ${ }^{110}$ and errors in the plaintiff's statement of his claim ${ }^{111}$ could also be cured by amendment. Plaintiffs were even permitted to add new counts to their writs if those counts were consistent with and for the same cause of action as the original counts, ${ }^{112}$ although such amendments would not be permitted if they added a new cause of action to the plaintiff's writ ${ }^{113}$ or otherwise affected a defendant's substantive rights. ${ }^{114}$ Amendments were

Harvard Law School Library) [hereinafter cited as Howe Lectures].

${ }^{106}$ All such motions of which there is a record were denied. See Clark v. Lowe, 15 Mass. 476 (1819); Little v. Putnam, [June 1806] Worc. C.P. 322; Hooper v. Clark, [June 1806] Worc. C.P. 324; Brimmer v. Hussey, [Sept. 1790] Essex C.P. 160; Lynde v. Eppes, [Sept. 1785] Essex C.P. 396.

${ }^{107}$ See Bowers v. Brown, [June 1780] Bris. C.P. 272.

${ }^{108}$ See Blood v. Harrington, 25 Mass. (8 Pick.) 552 (1829).

${ }^{109}$ See Richmond v. Shearman, [Aug. 1806] Berk. C.P. 88, appeal dismissed, [Sept. 1806] Berk. S.J.C. 386. Cf. Howe Lectures, supra note 105, at 118, [citing Ripley v. Warren, 19 Mass. (2 Pick.) 592 (1824)]. Contra, Hall v. Jones, 26 Mass. (9 Pick.) 446 (1830); Richardson v. Mooney, [Mar. 1818] Msex. C.P. Files.

${ }^{110}$ See Danielson v. Andrews, 18 Mass. (1 Pick.) 156 (1822). But see Yale v. Oliver, [Sept. 1825] Msex. C.P. Files.

${ }^{111}$ See Holmes v. Holmes, 19 Mass. (2 Pick.) 23 (1823) (error in allegation of length of seisin); Cuminge v. Rawson, 7 Mass. 440 (1811) (errors in description of close and nature of tort). Mere technical informalities often did not even require amendment. See Kennedy v. Carpenter, [July 1828] Suff. C.P. 22, n.41 (failure to allege notice of assignment of lease); Arey v. Wetmore, [Jan. 1797] Suff. C.P. 254, affd, [Feb. 1797] Suff. S.J.C. 26 (failure to allege consideration for promise or time at which payment promised); Jenks v. Ward, [Sept. 1789] Essex C.P. 340 (failure to allege that plaintiff in trespass was in the peace of the Commonwealth when assault occurred).

${ }^{112}$ See Swan v. Nesmith, 24 Mass. (7 Pick.) 220, 224-25 (1828);. Clarke v. Lamb, 23 Mass. (6 Pick.) 512, 515 (1828); Ball v. Claflin, 22 Mass. (5 Pick.) 303, 304-05 (1827); Tappan v. Austin, 1 Mass. 31 (1804); Howe Lectures, supra note 105, at 113-14. Cf. Parker v. Parker, 17 Mass. 376,379 (1821) (permitting plaintiff to restore count previously stricken when stricken count appeared best to conform to the evidence); Cane v. Wetmore (Hamp. S.J.C. 1794), in Dana, supra note 97 (permitting plaintiff to introduce evidence without necessity of amending declaration to conform thereto, since declaration gave adequate notice of claim). The mere addition of a new count would not discharge the bail or deprive the plaintiff of his priority over subsequent attaching creditors, see Miller v. Clark, 25 Mass. (8 Pick.) 412 (1829) (dictum); Ball v. Claflin, 22 Mass. (5 Pick.) 303, 305 (1827), unless the count was for a new cause of action. See Putnam v. Hall, 20 Mass. (3 Pick.) 445 (1826); Willis v. Crooker, 18 Mass. (1 Pick.) 204 (1822).

${ }^{113}$ See Pratt v. Bacon, 27 Mass. (10 Pick.) 123, 128 (1830); Vancleef v. Therasson, 20 Mass. (3 Pick.) 12 (1825) (dictum); Holbrook v. Gould, [Sept. 1828] Norf. C.P. 157. Thus, amendment would be denied if the original writ contained no count or declaration, see Brigham v. Este, 19 Mass. (2 Pick.) 420, 424-25 (1824); Gates v. Whitney, [Oct. 1825] Suff. C.P. 62, appeal dismissed, [Nov. 1825] Suff. S.J.C. 519; or if the proposed count were one which could not originally have been joined to the existing count. See Mason v. Waite, 18 Mass. (1 Pick.) 452 (1823) (by implication).

${ }^{114}$ See Briscoe v. Gale, (Msex. S.J.C. 1789), in Dana, supra note 97. See also Petition of Gardner, [Oct. 1829] Nan. C.P. 52 overruling objection to proposed amendment of writ of execution on the ground that substantive rights would be affected thereby). 
permitted after as well as before verdicts ${ }^{115}$ and upon documents other than original writs, such as bills of particulars. ${ }^{116}$ Sheriffs' returns of the mode of service of process and improper directions in writs concerning such service were also amendable,${ }^{117}$ with the result that technical lapses in the service of process were ignored $^{118}$ as long as actual service had been properly made. ${ }^{119}$ Thus, courts were slowly coming to the view that the only

${ }^{115}$ Stanwood v. Scovel, 21 Mass. (4 Pick.) 422 (1827); Williams v. Hingham \& Quincy Bridge \& Tpke. Corp., 21 Mass. (4 Pick.) 341, 349 (1826).

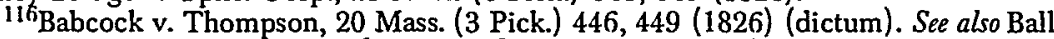
v. Hopkinton Cotton Mfg. Co., [Oct. 1820] Msex. S.J.C. 131 (amendment ordered, in eminent domain case, of description of land in jury venire).

${ }^{117}$ See Adams v. Robinson, 18 Mass. (1 Pick.) 461 (1823); Thatcher v. Miller, 13 Mass. 270, 271 (1816) (dictum); Welles v. Battelle, 11 Mass. 477, 481 (1814) (dictum); Campbell v. Stiles, 9 Mass. 217 (1812); Hearsey v. Bradbury, 9 Mass. 95 (1812); Swan v. French (Suff. S.J.C. 1789), in Dana, supra note 97. See also Commonwealth v. Parker, 19 Mass. (2 Pick.) 550, 561 (1824) (constable permitted to amend jury venire). But amendments by officers did not affect the rights of persons not party to the suit if those rights were acquired prior to the amendment. Emerson v. Upton, 26 Mass. (9 Pick.) 167 (1829). Cf. Williams v. Brackett, 8 Mass. 240 (1811) (officer cannot amend return in suit between parties other than the ones involved in the former action). Of course, a technical defect would still be fatal if the officer failed to amend his writ. See Ward v. Brigham, [Mar. 1809] Msex. C.P. Files; Reed v. Morris, [Sept. 1803] Worc. C.P. 14.5, rev'd on defaulh [Sept. 1803] Worc. S.J.C. 236; Brown v. Vorce, [Aug. 1793] Worc. C.P. 586; Clark v. Clark, [Mar. 1790] Msex. C.P. 517.

${ }^{118}$ See Lane v. Vernon, [Feb. 1787] Suff. S.].C. 24 (exception that deputy sheriff who served writ had taken oath of office before one justice of the peace instead of two justices quorum unus overruled).

${ }^{119}$ Basic rules as to service of process were not changed, however, in the postRevolutionary period. Normally, actions had to be commenced either by summons or capias, see Whitney v. Bigelow, [Dec. 1824] Worc. C.P. 229, affd, [Oct. 1826] Worc. S.J.C. 574; Act of Oct. 30, 1784, 1 [1780-1807] Laws of Mass. 199, although in exceptional cases the two forms of writ could be combined into one. See Cooke v. Gibbs, 3 Mass. 193 (1807) (opinion of Parsons, C.J.); Bullard v. Ware, [Dec. 1817] Msex. C.P. Files. Contra, Peirce v. Cody, [Aug. 1793] Worc. C.P. 557, appeal dismissed, [Sept. 1793] Worc. S.J.C. 233. If the service were by attachment, it was essential that actual valuable property of the defendant be attached; otherwise the service was invalid. For examples of such invalid service, see Bridge v. Marshall, [May 1798] Msex. C.P. Files, affd, [Apr. 1800] Msex. S.J.C. 327 ("a hat the property of the within named" defendant attached); Harrington v. Reed, [Mar. 1793] Msex. C.P. Files ("a log of wood" attached); Baker v. Baker, [Apr. 1784] Suff. C.P. Files (heir's interest in undistributed realty attached); Sprague v. Mansfield, [Apr. 1780] Suff. C.P. Files ("a certain note of hand" attached); Warren v. Mansfield, [Jan. 1780] Suff. C.P. Files ("public bills of credit of the United States" attached); Maynard v. Rice, [Mar. 1779] Msex. C.P. Files (goods "reputed to be Estate of" defendant attached). Moreover, service by attachment had to be accompanied by actual notice to the defendant. See Farr v. Barrows, [July 1794] Linc. S.J.C. 162. If service were by summons, it was insufficient simply to read the summons, see Spaulding v. Inhabitants of Charlestown, [Sept. 1790] Msex. C.P. Files. Rather, it was necessary to leave the summons at the defendant's last usual and permanent abode, see Richardson v. Judd, [Apr. 1824] Suff. C.P. Files (leaving summons at factory), even if the building had been destroyed, see Brown v. Hurlbut, [Mar. 1790] Berk. C.P. 226, but not if the defendant was an absent and absconding debtor in a suit pursuant to the trustee act. See Gold v. Stone, [Sept. 1788] Berk. C.P. 30. A return on a writ that the defendant could not be found within the server's precinct was, of course, an insufficient return, see Sullivan v. Gragg, [Sept. 1790] Msex. C.P. Files; Otis v. Claflin, [July 1783] Suff. C.P. Files; Wait v. Fecham, [Apr. 1783] Suff. C.P. Files; Phillips v. Farewell, [Apr. 1783] Suff. C.P. Files; Hatch v. Newell, [Apr. 1783] Suff. C.P. Files, as was a return that the defendant upon 
material issue was whether the defendant had had actual "personal notice and information of the service."120

One sees in the law of venue a parallel lessening of concern for form and a growing recognition that technical objections were of no significance as long as the forum was a fair and convenient one. The courts, for instance, rejected arguments that a corporation could have no residence for purposes of venue and hence could be sued only in the county of which the plaintiff was a resident; ${ }^{121}$ that a sheriff could be sued only in the county of which he was sheriff; ${ }^{122}$ and that, when an act committed in one county resulted in an injury in another, the plaintiff could bring suit only in the county of the act. ${ }^{123}$ As Chief Justice Parsons stated, venue was "considered [only] as a necessary part of technical form, but not as a substantial part of the writ." Elsewhere the Supreme Judicial Court noted that it accorded little weight to "an objection ... which was merely captious and dilatory in its nature; not at all affecting the merits of the action "125 "[C] ourts in all countries," said the judges, "have looked with disfavour upon the delay in proposing objections, which, through adherence to form, would obstruct the course of justice...."126

\section{THE DEVELOPMENT OF SUBSTANTIVE CATEGORIES OF LAW}

By the early nineteenth century, then, the concern in pleading was with substance, not with form. The emerging

arrest paid the debt in full, see Cunningham v. Felton, [Apr. 1783] Suff. C.P. Files, or was released at the creditor's command upon a part payment. See Webster v. Waite, [Jan. 1780] Suff. C.P. Files.

${ }^{120}$ Shearer v. Tappan, [Apr. 1798] Berk. C.P. 178.

${ }^{121}$ See Taunton \& Boston Tpke. Corp. v. Whiting, [Mar. 1810] Bris. C.P. 70.

${ }^{122} S_{e e}$ Foster v. Baldwin, 2 Mass. 569 (1786); Legate v. Porter, Cushing 80 (1786); Swan v. French, (Suff. S.J.C. 1789), in Dana, supra note 97; Bright v. Henderson, [Nov. 1785] Msex. C.P. 282.

${ }^{123}$ See Barden v. Crocker, 27 Mass. (10 Pick.) 383, 390-91 (1830). Cf. Thompson v. Crocker, 26 Mass. (9 Pick.) 59 (1829) (proof that act causing injury was committed in county other than one in which suit was brought and venue laid held an immaterial variance).

${ }_{124}$ Briggs v. Nantucket Bank, 5 Mass. 94, 96 (1809).

${ }^{125}$ Kincaid v. Howe, 10 Mass. 203, 205 (1813).

${ }^{126}$ Ripley v. Warren, 19 Mass. (2 Pick.) 592, 594 (1824). Accordingly the court held that "all dilatory pleas, or those which amount only to an exception to the form of the process, are required to be exposed to the view of the court in the first stage," id. at 594, when the plaintiff still had a right to amend, and that failure to make timely objection constituted a waiver thereof. See Prescott v. Tufts, 7 Mass. 209 (1810); Gilbert v. Nantucket Bank, 5 Mass. 97 (1809); Cleveland v. Walsh, 4 Mass. 591 (1808); Livermore v. Boswell, 4 Mass. 437 (1808); Whiting v. Hollister, 2 Mass. 102 (1806); Barrell v. Farley, [Apr. 1789] Msex. S.J.C. 160. Cf. Smith v. Bowker, 1 Mass. 76 (1804). But see 
concern for substance was of great significance, for it compelled the bench and bar to think about law in substantive categories, such as "tort" and "contract," 27 rather than the old procedural categories of trespass, assumpsit and the like.

Once men began to think in these new categories, the ancient system of common law writs began to collapse. Although defendants throughout the half century after the Revolution could procure the dismissal of writs which failed to indicate the "kind of Plea or Action ... brot by the Plft [sic] ...,"128 which joined two forms of action, ${ }^{129}$ or which sought recovery in the wrong form of action ${ }^{130}$ or were otherwise "informal"131 or insufficient, ${ }^{132}$ many plaintiffs nonetheless recovered judgments upon writs containing such defects when their opponents either failed to object or raised their objection unseasonably. ${ }^{133}$ There

Rathbone v. Rathbone, 21 Mass. (4 Picḱ) 89 (1826) (plea in abatement by defendant who lacked notice of suit not waived by delay).

127 See Haggins v. Henderson, (Suff. S.J.C. 1793), in Dana, supra note 97; Williams v. Gore (Suff. S.J.C. 1792), in id; Henderson v. Bethume (Suff. S.J.C. 1791), in id.

${ }_{128}$ Watson v. Robinson, [Aug. 1789] Hamp. C.P. 121.

${ }^{129}$ See Harris v. Fullam, [Mar. 1807] Worc. C.P. 405 (demurrer for joining count in tort for injuring plaintiff's horse and count in contract for not paying therefor sustained); Barker v. Burrell, [July 1805] Suff. C.P. 3 (plaintiff in trespass nonsuited for joining to writ declaration lying in case); Schermerhorn v. Willard, [Jan. 1797] Berk. C.P. 160, appeal dismissed, [Oct. 1798] Berk. S.J.C. 123 (demurrer for joining claims on bond and promissory note sustained); Codman v. Henderson, [July 1789] Suff. C.P. 57, rev'd on defaulh [Feb. 1790] Suff. S.J.C. 26 (abated for joining counts against sheriff in tort for not serving writ and in contract for breach of promise to serve it). But 2 varieties of the same form of action, such as trover, a variety of case, and case, could be joined. See Ayer v. Bartlett, 26 Mass. (9 Pick.) 156, 161 (1829).

${ }^{130}$ See Lienow v. Ritchie, 25 Mass. (8 Pick.) 235 (1829) (landlord not in possession of premises must bring case, not trespass, for damages done thereto by a stranger); Jones v. Hoar, 22 Mass. (5 Pick.) 285 (1827) (landowner must sue in trespass or trover for cutting and taking of his trees, unless defendant took trees in pursuance of an agreement or had sold the trees); Lane v. Smith, 19 Mass. (2 Pick.) 281 (1824) (quaere whether debt can be brought on a bail bond); Hayden v. Shed, 11 Mass. 500 (1814) (case, not trespass, proper form of action when goods attached upon writ which is subsequently abated); Agry v. Young, 11 Mass. 220 (1814) (trespass, not case, proper form of action against assessors for wrongful assessment); Banorgee v. Hovey, 5 Mass. 11, 24-26 (1809) (assumpsit will not lie when contract embodied in a bond, even if the bond fails to join all parties to the original contract); Adams v. Hemmenway, 1 Mass. 145 (1804) (case, not trespass, lies for indirect injury to profits lost as a result of attempts made to save life of a victim of gunshot wound inflicted by defendant). But cf. White v. Moseley, 25 Mass. (8 Pick.) 356 (1829) (trespass lies for damage to mill resulting from defendant's destruction of plaintiff's mill dam); Wiswall v. Austin, [Mar. 1788] Worc. C.P. 469, rev'd on other grounds, [Sept. 1788] Worc. S.J.C. 2 (debt proper form of action for statutory penalty for usury).

${ }^{33} i_{\text {Lovell v. Francis, [Mar. 1803] Nan. C.P. } 8 .}$

${ }^{132}$ Bigelow v. Barker, [May 1816] Nan. C.P. 165.

${ }^{133}$ As to lateness of objection, see Whitney v. Russell, [Dec. 1782] Msex. S.J.C. 363 (motion in arrest of judgment overruled in "plea of taking imprisoning and detaining" the plaintiff); Sacket v. Bishop, [Nov. 1822] Hamp. C.P. 21 (motion in arrest for suing in case rather than trespass in wagon collision case overruled); Maynard v. Currant, [July 1806] Suff. C.P. 37 (motion in arrest for joining causes of action for breach of contract 
were, for example, many actions in which plaintiffs were victorious which were given no name-one was labelled merely "a plea of Grievous complaint;"134 another, a "Plea of the for the Recovery" of certain nails; ${ }^{135}$ a third, "a Plea for not performing his [the defendant's] promise." ${ }^{136}$ Others merely stated the facts upon which the plantiffs relied. ${ }^{137}$ There were also cases in which plaintiffs gave their writs the substantive name of their cause of action rather than their proper formal name-pleas, for instance, of "Trover \& conversion,"138 of "Assault \& Battrey,"139 of "Defamation" 140 and of "possession." concerning the propriety and forms of writs were "gradually relaxed"142 and ignored, in still other cases, plaintiffs either brought the wrong writ-covenant and debt upon an unsealed agreement, ${ }^{143}$ case upon a sealed agreement ${ }^{144}$ case for dower, ${ }^{145}$ or case for a trespass committed with force and arms ${ }^{146}$-or joined two forms of action in a single writ, ${ }^{147}$ and nonetheless were able to recover judgment.

and for statutory penalty overruled). But see Paul v. Frazer, [Jan. 1807] Suff. C.P. 263, affd, [Mar. 1807] Suff. S.J.C. 203 (motion in arrest for failure to state a cause of action granted).

${ }^{134}$ Coe v. Cornwall, [Aug. 1801] Hamp. C.P. 154, appeal dismissed, [May 1802] Hamp. S.J.C. 435.

${ }^{135}$ Lumbart v. Washbourn, [Oct. 1797] Dukes C.P.

${ }^{136} \mathrm{King}$ v. Sykes [May 1783] Hamp. C.P. 240. Accord, Shaw v. Billings, [May 1795]

Hamp. C.P. 122; Phelps v. Munroe, [Jan. 1793] Hamp. C.P. 131; Pearce v. Bucklin, [Sept. 1781] Bris. C.P. 371, rev'd on default, [Oct. 1781] Bris. S.J.C. 101.

${ }^{137}$ See Corsa v. Noble, [Oct. 1799] Berk. S.J.C. 242; Lumbert v. Hoyt, [Oct. 1804]

Nan. C.P. 103; Porter v. Atwater, [Nov. 1798] Hamp. C.P. 332; Sumner v. Lackor, [Sept. 1798] Hamp. C.P. 126.

${ }^{138}$ Remington v. Palmer, [Sept. 1811] Hamp. S.J.C. 260. Accord, Barney v. Mason,

[Oct. 1799] Bris. S.J.C. 102; Wheelock v. Tupper, [Oct. 1783] Nan. C.P. 306. See also

Divol v. Gibbs, [Nov. 1782] Bris. S.J.C. 312 ("Case for trover").

${ }^{139}$ Nosavet v. Stat, [Oct. 1788] Dukes C.P.

${ }^{140}$ Athcarn v. Hancock, [Oct. 1793] Dukes C.P.

${ }^{14}$ ISewell v. Sawyer, [May 1804] Hamp. C.P. 69.

142 Jones v. Hoar, 22 Mass. (5 Pick.) 285 n. (1827).

${ }^{143}$ See Ewer v. Handy, [Oct. 1801] Nan. C.P.; Luce v. Volintin, [Apr. 1798] Dukes C.P.; Sears v. Easton, [Feb. 178.5] Hamp. C.P. 129.

${ }^{144}$ See Jenkins v. Brewster, [Sept. 1817] Hamp. S.J.C. 134; Williams v. Sampyon, [Aug. 1787] Suff. S.J.C. 172; Parkman v. Jefferson, [Oct. 1821] Suff. C.P. 418; Swett v. Poor, [Sept. 1813] Essex C.P. 35, affd, [Nov. 1814] Essex S.J.C. 98; Hinckley v. George, [Mar. 1800] Nan. C.P.; Taylor v. Eustis, [July 1798] Suff. C.P. 259, aff'd, [Aug. 1799] Suff. S.J.C. 197. Cf. Clary v. Parling, [Apr. 1785] Worc. S.J.C. 126 (case upon an agreement "in imitation of a Penal obligation").

${ }^{145}$ See Norton v. Norton, [Apr. 1794] Dukes C.P.; Harris v. Fuller, [Aug. 1778] Hamp. C.P. 228.

${ }^{146}$ See White v. Jewett, [Jan. 1799] Hamp. C.P. 14, rev'd on default, [Sept. 1800]

Hamp. S.J.C. 307. Cf. Wood v. Vose, [Mar. 1793] Nan. C.P. 85 (case for assault); Bradford v. Stark, [Sept. 1777] Bris. C.P. 185 (case for assault), rev'd on other grounds, [Oct. 1778] Bris. Super. Ct. 37 (where writ is labeled as trespass).

${ }^{147}$ See Penniman v. Shaw, [Apr. 1810] Suff. C.P. 674 (counts against sheriff for tort for not serving writ and for breach of promise to serve it joined). Cf. Mixer v. Johnson, [Dec. 1790] Worc. C.P. 409 (debt and case for recovery of statutory penalty joined). 
It is impossible to attribute all these departures from proper form solely to carelessness on the part of court clerks, attorneys and parties not represented by attorneys. ${ }^{148}$ Many of the departures, in fact, appear to have been conscious attempts on the part of skilled attorneys to compel the courts to focus on the substantive rather than the procedural aspects of their cases, perhaps in order to obtain some tactical advantage. ${ }^{149} \mathrm{~A}$ clear illustration of such an attempt is Taylor v. Eustis, ${ }^{150}$ a contract action in which the plaintiff pleaded the existence of a sealed promise by the defendant for which consideration had been given. The plaintiff's successful attempt to sue in case rather than in debt appears to have been a conscious attempt to subsume sealed as well as unsealed promises under a single substantive rubric of contract for which a plaintiff could have an election of remedies; that is, either in debt, where the court might determine the amount of damages, ${ }^{151}$ or in assumpsit, where damages would be fixed by the jury. ${ }^{152}$ Despite the fact that considerable support existed for it, ${ }^{153}$ this particular attempt would fail in the next decade. ${ }^{154}$ However, in many other instances the Supreme Judicial Court ceased to analyze claims in procedural terms and instead began to recognize that plaintiffs possessed substantive rights for the enforcement of which they could elect one of several writs. In suits for statutory penalties, for instance, where the statute did not prescribe the remedy, a plaintiff could bring either trespass, ${ }^{155}$ debt $^{156}$ or case. ${ }^{157}$

${ }^{148}$ Some of the departures, however, can be so attributed. See, e.g., Parkman v. Jefferson, [Oct. 1821] Suff. C.P. 418 (writ of case on a bond, to which the defendant pleaded that he owed nothing, the proper plea to a writ of debt on a bond); Lumbart v. Washbourn, [Oct. 1797] Dukes C.P. ("Plea of the for the Recovery" of certain nails). In the former action, a clerk probably substituted the word "case" for "debt"; in the latter, a clerk probably left out the name of the action.

${ }^{149}$ See, e.g., Coe v. Cornwall, [Aug. 1801] Hamp. C.P. 154, appeal dismissed, [May 1802] Hamp. S.J.C. 435 ("a plea of Grievous complaint" brought by George Bliss, Esq.); King v. Sykes, [May 1783] Hamp. C.P. 240 ("a Plea for not performing his promise" brought by Moses Bliss, Esq.).

${ }^{150}[$ [July 1798] Suff. C.P.259, aff'd, [Aug. 1799] Suff. S.J.C. 197.

${ }^{151}$ Seenote 170 infra.

${ }^{152}$ See W. Nelson, supra note 63 , at $410 \mathrm{n} .28$.

${ }^{153}$ See Banorgee v. Hovey, 5 Mass. 11, 26-35 (1809) (dissenting opinion).

${ }^{154}$ See Richards v. Killam, 10 Mass. 239 (1813); Kimball v. Tucker, 10 Mass. 192 (1813); Banorgee v. Hovey, 5 Mass. 11, 24-26 (1809).

${ }_{155}$ See Reed v. Davis, 25 Mass. (8 Pick.) 514, 516 (1829) (dictum); Peirce v. Spring, 15 Mass. 489 (1819).

${ }^{156}$ See Reed v. Davis, 25 Mass. (8 Pick.) 514 (1829); Jeffrey v. Bluehill Tpke. Corp., 10 Mass. 368, 370-71 (1813); Bigelow v. Cambridge \& Concord Tpke. Corp., 7 Mass. 202, $204(1810)$.

${ }^{157}$ See Peabody v. Hoyt, [Apr. 1811] Suff. C.P. 173, rev'd on other grounds, [Mar. 1813] Suff. S.J.C. 243; Scales v. Williams, [Dec. 1805] Msex. C.P. 150, appeal dismissed, [Oct. 1806 ] Msex. S.J.C. 255; Brooks v. Stow, [Aug. 1790] Worc. C.P. 285. 
Similarly, a plaintiff could maintain trespass, trover or assumpsit against a trespasser who cut and sold his trees; ${ }^{158}$. trespass or case for damages from a runaway horse frightened by the discharge of a gun; ${ }^{159}$ indebitatus assumpsit or account against a bailiff; ${ }^{160}$ debt or case for misbehavior by a public officer; ${ }^{161}$ and, during much of the early nineteenth century, trespass or case against a sheriff for a trespass committed by his deputy. ${ }^{162}$

The Supreme Judicial Court's preference for substance over form was explicitly enunciated in Cole $v$. Fisher, ${ }^{163}$ where it held "a contest about the form of action ... [to] be of little avail to the defendant" and left "the case to the jury, to settle it as a question of fact, upon the principles ... [therein] stated." refused in another case "to disturb ... [a] verdict upon a question of form only," when "upon the whole, justice ha[d] been done between the parties." 165 The sole concern of the court had become the existence or nonexistence of a substantive right in the plaintiff. If he had such a right or had suffered "injuries ... or wrongs .... in his person, property, or character," the Massachusetts constitution provided that he "ought to find a certain remedy, by having recourse to the laws ...."166 Thus, if a plaintiff had a right but could not obtain a writ conforming to the usual forms, it was, nonetheless, "the ... constant practice of the court to grant him a writ, by which he may obtain his remedy," ${ }^{67}$ or to permit him to plead without writ. ${ }^{168}$

Substance also triumphed over form in the emergence of new rules of defensive pleading. In pre-Revolutionary law, it will be recalled, each writ had its own proper general issue. If a defendant pleaded the wrong general issue, his plea was held insufficient and was rejected. By the 1790's, however, the sufficiency of a defendant's plea was coming to depend

${ }^{158}$ See Bigelow v. Jones, 27 Mass. (10 Pick.) 161, 165 (1830) (dictum).

${ }^{159}$ See Cole v. Fisher, 11 Mass. 137, 139 (1814) (by implication).

160 See Jones v. Harraden, Cushing 62, 64-65 (Suff. S.J.C. 1784).

${ }^{161}$ See M'Millan v. Eastman, 4 Mass. 378, 382 (1808).

${ }^{162}$ See Grinnell v. Phillips, 1 Mass. 530, 538 (1805) (allowing trespass as a remedy). See also Campbell v. Phelps, 18 Mass. (1 Pick.) 62, 69 (1822) (dictum that Grinnell v. Phillips was the first instance in which trespass instead of case was held a proper remedy). But see Campbell v. Phelps, 17 Mass. 244, 246 (1821) (holding trespass to be the sole remedy).

16311 Mass. 137 (1814).

${ }^{164}$ Id. at 139 .

${ }^{165}$ Booden v. Ellis, 7 Mass. 507, 508-09 (1811).

166 MASS. ConST. pt. I, art. XI (1780).

${ }^{167}$ Cooke v. Gibbs, 3 Mass. 193, 196 (1807).

${ }^{168}$ For an example of pleading without writ, see Hubbard v. Hubbard, 6 Mass. 397 (1810). See also Ross v. Ross, [Oct. 1793] Nan. C.P. 96 (wife without writ "complain[ed] against" her husband that he beat and threatened her, forcing her to flee). 
increasingly upon the substantive nature of the suit brought against him, rather than upon the form of action which the plaintiff had used. The propriety of a defensive plea, as one lower court explained, was no longer measured by technical rules, but "in the common scales of Justice by the weights of Law." 169 Thus, if a plaintiff had a cause of action for which he could bring one of several forms of action, it became the rule that the defendant could plead the general issue appropriate to any of those forms. Suits for statutory penalties are particularly illustrative. Such suits could be brought in debt, case or trespass. Before the Revolution a defendant was required to plead that he was not indebted, if the plaintiff chose to bring his writ in debt; or not guilty, if the plaintiff chose either case or trespass. Although it remained true that not indebted was the more proper plea, ${ }^{170}$ in the late 1780 's, it became the practice for defendants to plead not guilty to writs of debt $^{171}$ as well as to writs of case and trespass. Likewise, by the 1790's, pleas of not guilty had become acceptable in response to writs of case ${ }^{172}$ and debt $^{173}$ brought against executors for legacies, whereas in the pre-Revolutionary period the plea of never promised had been the only proper response to a writ of case, and the plea of not indebted the proper response to a writ of debt. ${ }^{174}$ Not indebted also became available to executors sued in case. ${ }^{175}$ Similarly, in

${ }^{169}$ Third Parish v. Gay, [Sept. 1796] Norf. C.P. 396.

${ }^{170}$ Stilson v. Tobey, 2 Mass. 521 (1807). One difference between the pleas was that on a plea of not indebted the jury awarded the penalty, whereas the court did so on a plea of not guilty. Commonwealth v. Stevens, 15 Mass. 195 (1818).

${ }^{17}$ See Eddy v. Oliver, [June 179.5] Linc. S.J.C. 160 (jury verdict of guilty in part); Metcalf v. Rawson, [Feb. 1789] Suff. S.J.C. 116 (jury verdict of guilty); Davenport v. Lamson, [Dec. 1803] Worc. C.P. 226, appeal dismissed, [Apr. 1806] Worc. S.J.C. 366 (jury verdict of not guilty); Pearley v. Bagley, [Oct. 1799] Essex C.P. 433, affd, [Nov: 1800] Essex S.J.C. 332 (plea of not guilty upheld below and jury verdict of not guilty on appeal); Thayer v. Wallack [Jan. 1791] Suff. C.P. 201, affd, [Aug. 1791] Suff. S.J.C. 215 (same); Barker v. Story, [Jan. 1789] Suff. C.P. 185, appeal dismissed, [Aug. 1789] Suff. S.J.C. 242 (plea of not guilty upheld); Winslow v. Sears, [Sept. 1787] Worc. C.P. 427, rev'd on other grounds, [Sept. 1787] Worc. S.J.C. 228 (plea of not guilty upheld below and then waived on appeal, where jury found defendant was indebted).

${ }^{172}$ See Allen v. Carter, [Sept. 1792] Worc. S.J.C. 213 (jury verdict of not guilty); Hatch v. Hatch, [July 1804] Suff. C.P. 230 (plea of not guilty upheld). But see Joselyn v. Hudley, [Apr. 1793] Ply. C.P. 181 (plea of not guilty rejected).

${ }^{173}$ See Storer v. Stowell, [July 1794] Suff. C.P. 118, affd, [Aug. 1795] Suff. S.J.C. 195 (plea of not guilty upheld below; jury verdict of not indebted on appeal). Cf. Holker v. Bulfinch, [Jan. 1794] Suff. C.P. 39 (plea of never promised upheld in writ of debt).

${ }^{174}$ Compare Willard v. Flagg, [June 1774] Worc. C.P. 372 (case; plea of never promised upheld), and Loring v. Loring, [Oct. 1772] Ply. C.P. 428 (debt; plea of not indebted upheld), with Atkins v. Russell, [Sept. 1768] Essex C.P. 343 (case; plea of not by law chargeable rejected), and Parsons v. Kinsman, [Dec. 1774] Essex C.P. 311 (debt; plea of never requested to pay rejected).

${ }^{175}$ See Besom v. Grant, [Apr. 1794] Essex C.P. 376. Cf. Wilkins v. Wilkins, [Oct. 1797] Essex C.P. 211, appeal dismissed, [June 1798] Essex S.J.C. 72 (plea of payment upheld). 
replevin, it became permissible in the 1790's to plead, in addition to the pleas appropriate to replevin, that one was not guilty. ${ }^{176}$ The significance of these new rules lies in their apparent recognition that the commission of a statutory wrong, the failure of an executor to pay a legacy, and the wrongful taking of a chattel constituted some generic form of wrong-a tort-for which a plaintiff could bring a variety of different writs to obtain damages or some other form of restitution, and concerning which a defendant ought to have a similar election, either to plead generically that he was not guilty of the tort or to plead in the form appropriate to the plaintifís's particular action. ${ }^{177}$

One finds a similarly emerging substantive concept of contract by looking at the changing rules of defensive pleading in writs of debt, covenant and assumpsit. In pre-Revolutionary law, each had had its own proper general issue, but by the 1790's strict pleading rules had disappeared. Thus, it became possible to enter the assumpsit plea of never promised to writs of covenant ${ }^{178}$ and debt, ${ }^{179}$ or the debt plea of not indebted to a writ of assumpsit. ${ }^{180}$ In one writ of assumpsit, a jury even returned a hybrid verdict that the defendant both was indebted and had

${ }^{176} S_{e e}$ Rogers v. Adams, [Aug. 1800] Ply. C.P. 128, rev'd on other grounds, [June 1801] Ply. S.J.C. 104 (plea of not guilty upheld below; jury verdict that defendant took goods on appeal); Howe v. Symmes, [A pr. 1799] Suff. C.P. 89, rev'd on other grounds, [Feb. 1800] Suff. S.J.C. 18 (plea of not guilty upheld below; jury verdict of property in plaintiff on appeal); Soul v. Winthrop, (July 1793] Suff. C.P. 162, affd, [Aug. 1793] Suff. S.J.C. 201 (plea of not guilty upheld below; jury verdict of property in defendants on appeal).

${ }^{177}$ Defendants retained the right to plead to the specific form of action. See Miller v. Hartshorne, [Feb. 1799] Suff. S.J.C. 119 (jury verdict in replevin that property not in plaintiff); Kirkwood v. Prout, [June 1793] Cumb. S.J.C. 116 (jury verdict in writ of debt that defendant indebted); Butman v. Hutson, [June 1792] Essex S.J.C. 125 (jury verdict in replevin that property not in third person as alleged by defendant); Benson v. Bell, [Jan. 1806] Suff. C.P. 500 (plea in replevin of never took upheld); Rice v. Brigham, [Aug. 1800] Worc. C.P. 385, appeal dismissed, [Sept. 1800] Worc. S.J.C. 527 (jury verdict of not guilty in writ of case for statutory penalty); Dutch v. Mighill, [Apr. 1799] Essex C.P. 169, appeal dismissed, [June 1799] Essex S.J.C. 189 (plea of never promised upheld in writ of case against executor); Townsend v. Fayerweather, [Mar. 1799] Msex. C.P. 109, rev'd on default, [Apr. 1801] Msex. S.J.C. 15 (same).

${ }^{178}$ See Winsor v. Rich, [Oct. 1810] Ply. S.J.C. 21; Stearns v. Barrett, [Oct. 1821] Suff. C.P. 32; Peck v. Jackson, [Oct. 1799] Suff. C.P. 227, appeal dismissed, [Aug. 1800] Suff. S.J.C. 79; Winsor v. Edes, [Apr. 1799] Ply. C.P. 486; Vaughan v. Woods, [July 1798] Suff. C.P. 322, rev'd by referees, [Feb. 1799] Suff. S.J.C. 141; Wady v. Tallman, [Mar. 1792] Bris. C.P. 80.

${ }^{179}$ See Kent v. Woodward, [Jan. 1804] Suff. C.P. 1; Sullivan v. Blake, [Jan. 1800] Suff. C.P. 85, rev'd on default, [Aug. 1800] Suff. S.J.C. 76. Cf. Pynes v. Allen, [Apr. 1814] Ply. C.P. 396, appeal dismissed, [Oct. 1814] Ply. S.J.C. 76 (plea of never promised upheld in action of account).

${ }^{180}$ See Frothingham v. Soley, [Jan. 1799] Suff. C.P. 164, appeal dismissed, [Feb. 1800] Suff. S.J.C. 40; Coffin v. Folger, [Mar. 1797] Nan. C.P. 173; Bordman v. Stewart, [Oct. 1791] Suff. C.P. 64, rev'd on default [Feb. 1792] Suff. S.J.C. 18; Moore v. Titcomb, [Apr. 1788] Essex C.P. 335; Rogerson v. Howard, [Jan. 1788] Suff. C.P. 51; Winslow v. Pitcher, [Apr. 1782] Ply. C.P. 327. Cf. Devens v. Bryant, [Jan. 1789] Suff. C.P. 213, rev'd on default, [Feb. 1789] Suff. S.J.C. 146 (plea of non est factum upheld). 
promised, ${ }^{181}$ while in one plea of covenant, the court upheld a plea that the defendant never covenanted ${ }^{182}$-an adaptation to the writ of covenant of the assumpsit plea of never promised. In these cases, in short, the ancient categories of debt, covenant and assumpsit were being blurred, and a new category of contract, under which lawyers were seeking to subsume the entire law of obligation, was emerging. ${ }^{183}$

One way in which lawyers sought to place all of the law of obligation within the catagory of contract was by transposing the doctrine of consideration into two sorts of action where proof thereof had not previously been required-suits on negotiable and on sealed instruments. As a result, by the beginning of the nineteenth century in a suit by the original promissee, the maker of a promissory note could introduce in his defense evidence not only of an illegal consideration ${ }^{184}$ or a failure of consideration, ${ }^{185}$ but even of a want of consideration in the original transaction, which would render the note "void as a nudum pactum." 186 These

${ }^{181}$ See Alden v. Milikan, LJune 1793] Cumb. S.J.C. 164.

${ }^{182}$ See Quincy v. Shaw, [July 1795] Suff. C.P. 64.

${ }^{183}$ Apparently, however, there existed some recognition during the 1790 's of subcategories within the general category of contract. In particular, it appears that debt, covenant and indebitatus assumpsit were regarded as one subcategory distinct from another, special assumpsit. Thus, pleas of not guilty became proper in writs of debt, see Lindsey v. House, [Apr. 1800] Ply. C.P. 83, appeal dismissed, [June 1801] Ply. S.J.C.99; Storer v. Stowell, [July 1794] Suff. C.P. 118, affd [Aug. 179.5] Suff. S.J.C. 195 (plea of not guilty upheld below; jury verdict of not defendant's deed on appeal); covenant, see Drew v. Edes, [Apr. 1801] Ply. C.P. 224, appeal dismissed, [June 1801] Ply. S.J.C. 106; Bolter v. Proprietors of Hay Market Theater, [Apr. 1798] Suff. C.P. 41, appeal dismissed, [Feb. 1799] Suff. S.J.C. 150; Smith v. Knoepsel, [July 1797] Suff. C.P. 147, affd, [Feb. 1798] Suff. S.J.C. 5 (plea of not guilty upheld below; special verdict on appeal); Villiers v. Tyler, [July 179.5] Suff. C.P. 150; Shaw v. Jackson, [July 1795] Suff. C.P. 65, affd, [Aug. 1796] Suff. S.J.C. 208 (plea of not guilty upheld below; jury verdict of did not keep covenant on appeal); Beals v. Barrow, [Aug. 1791] Suff. S.J.C. 224 (jury verdict of guilty); and indebitatus assumpsit, see Barnard v. Hulbert, [Jan. 1803] Berk. C.P., appeal dismissed, [May 1804] Berk. S.J.C. 204; Walter v. Guppy, [July 1799] Suff. C.P. 151, rev'd by referees, [Feb. 1800] Suff. S.J.C. 34; Endicot v. Sumner, [July 1789] Suff. C.P. 86, affd, [Feb. 1790] Suff. S.J.C. 27 (plea of not guilty upheld below; jury verdict of never promised on appeal). Where no promise on the part of the defendant needed to be proved by the plaintiff, a plea of never promised would have been inappropriate on the facts. Pleas of not guilty were throughout the 1790's held inappropriate upon writs of special assumpsit, see Frothingham v. Patten, [Jan. 1794] Suff. C.P. 16; Storer v. Wilder, [Jan. 1793] Suff. C.P. 43; Read v. Shearman, [Mar. 1791] Bris. C.P. 43, where a promise on the part of the defendant did have to be proved by the plaintiff and a plea of never promised was therefore appropriate.

${ }^{184}$ See Wheeler v. Russell, 17 Mass. 258, 281 (1821); Russell v. De Grand, 15 Mass. 35 (1818); Allen v. Shearman, [Dec. 1807] Bris. C.P. 640 .

${ }_{18.5}$ See Knapp v. Lee, 20 Mass. (3 Pick.) 452, 457 (1826).

${ }^{186}$ Fowler v. Shearer, 7 Mass. 14, 22 (1810). Accord, Boutell v. Cowdin, 9 Mass. 254 (1812); Bliss v. Negus, 8 Mass. 46 (1811). See also Hill v. Buckminster, 22 Mass. (5 Pick.) 391 (1827) (note given in renewal of a note which was void for want of consideration is also void); Whitcomb v. Williams, 21 Mass. (4 Pick.) 228 (1826) (permitting a maker of a note who failed to make a defense of want of consideration in a suit on the note to maintain a new suit to recover back the money paid on the note). Contra, Stackpole v. Arnold, 11 Mass. 27, 32 (1814). 
cases led, in turn, to a reversal of the colonial rule ${ }^{187}$ that a plaintiff in a suit upon a note did not have to plead and prove consideration; an 1827 case clearly held that he did. ${ }^{188}$ For a brief time near the turn of the century, the courts even held that a defense "that there was no Cons. for the Note" could "be gone into" in a suit by an endorsee against a maker, ${ }^{189}$ although ultimately they rejected such a rule in response to the needs of the commercial community, which used negotiable securities as "a substitute for money" and "a circulating medium." 190 By 1830 , the courts had arrived at the modern view that a maker cannot go into the defense of consideration in a suit by the endorsee, unless the endorsee obtained the note after maturity or otherwise did not fulfill the requirements of being a holder in due course. ${ }^{191}$

Similar efforts were made by defendants in suits upon sealed instruments to go into questions of consideration. One lower court in 1800 , for example, held a bond under seal void because it had been given for an illegal consideration, ${ }^{192}$ while several years earlier Theophilus Parsons, who would subsequently become Chief Justice of Massachusetts, had argued that a "covent: ... [was] void for want of Cons." "193 There were at least two categories of cases in which the courts accepted Parsons' argument and permitted defendants to impeach a sealed instrument for want of consideration: cases of covenants not to compete, ${ }^{194}$ and cases in which a receipt of consideration was not averred in the deed sued on by the plaintiff. ${ }^{195}$ Moreover, as late as the 1820's, the Supreme Judicial Court was "not prepared to say" whether "a failure of consideration ... . [would] avoid a deed." 196 But by 1810 , after a decade of confusion, it had become

${ }^{187} \mathrm{See}$ W. Nelson, supra note 63 , at $97-98$.

${ }^{188} S_{e e}$ Hemmenway v. Hickes, 21 Mass. (4 Pick.) 497, 500 (1827).

${ }^{189}$ Micah v. Clap, (Hamp. S.J.C. 1792), in Dana, supra note 97. See also Lyman v. Leavitt, (Hamp. S.J.C. 1799), in Dana, supra note 97 (defendant maker of a promissory note argued that "the want of such Cons. prevent[ed] the Indorsee the Plt: from recovering in this Action").

${ }^{190}$ Sumner v. Williams, 8 Mass. 162, 191 (1811).

191 See Grew v. Burditt, 26 Mass. (9 Pick.) 265 (1830); Bartlett v. Skinner, [Aug. 18301 Worc. C.P. 403.

${ }^{192}$ Page v. Trufant, [Sept. 1800] Msex. C.P. 257.

${ }^{193}$ Parker v. Mather, (Msex. S.J.C. 1792), in Dana, supra note 97.

${ }^{194}$ See Pierce v. Woodward, 23 Mass. (6 Pick.) 206 (1828); Palmer v. Stebbins, 20 Mass. (3 Pick.) 188, 193 (1825); Perkins v. Lyman, 9 Mass. 522, 530 (1813); Pierce v. Fuller, 8 Mass. 223, 226 (1811).

${ }^{195}$ Sumner v. Williams, 8 Mass. $162,186-89$ (1811); see Davenport v. Mason, 15 Mass. 85, 91-92 (1818), overruled on other grounds, Jacobs v. Peterborough \& Shirley R.R. Co., 62 Mass. (8 Cush.) 223 (1851).

${ }^{196}$ Stearns v. Barrett, 18 Mass. (1 Pick.) 443, 448-49 (1823). 
clear that, except in the special categories noted above, a total want, as distinguished from a failure of consideration, would not avoid a deed. In the words of the court, a "covenant...., although voluntary and gratuitous on the part of [its makers, would] yet [be] binding on them ....

Even in reaching this result, however, the courts came to analyze sealed contracts under the broader, more general rubric of contract. The rule at which they arrived in covenant cases, for instance, was not that consideration was not a requisite of sealed as well as unsealed contracts, but that proof of consideration was not needed in the former case, because "[a] bond, from the solemnity of its execution, import[ed] a consideration."198 Accordingly, one could not impeach the bond for a want of consideration, although one could "avoid the bond, by shewing that it was obtained by fraud or duress, or that the consideration [was] illegal or against the policy of the law." 199 Perhaps one could also show that the consideration had failed. ${ }^{200}$ Moreover, although the courts refused to permit a defense of want of consideration in suits on sealed instruments, they did treat sealed contracts like other contracts in several other ways. One was to apply the same measure of damages in covenant as in assumpsit; ${ }^{201}$ another was to hold that a contract under seal, like any other contract, could be discharged by a new parol agreement ${ }^{202}$ for which a consideration deemed by the parties to be full and adequate had been given. ${ }^{203}$

The breakdown of the old formulary categories and the emergence of new substantive ones can also be seen by studying pleas offered in defense to cases on the borderline between the newly emerging categories of tort and contract. By the 1790's, for example, a defendant had the option, in suits against sheriffs for their own or their deputies' misfeasance; ${ }^{204}$ in suits against

${ }^{197}$ Upham v. Smith, 7 Mass. 265, 266 (1811); accord, Mitchell v. Kingman, 22 Mass.

(5 Pick.) 431, 433 (1827) (by implication).

${ }_{198}$ Page v. Trufant, 2 Mass. 159, 162 (1806) (opinion of Parsons, C.J.).

199 Id. at 162 .

${ }^{200}$ See note 194 supra \& accompanying text.

${ }^{201}$ See Harris v. Newell, 8 Mass. 262 (1811); Caswell v. Wendell, 4 Mass. 108, 110 (1808); Bickford v. Page, 2 Mass. 455, 461 (1807); Marston v. Hobbs, 2 Mass. 433, 440 (1807).

${ }_{202}$ Munroe v. Perkins, 26 Mass. (9 Pick.) 298, 303-05 (1830); see Randall v. Rich, 1 Mass. 494 (1814). See also Bacon v. Kingman, [Sept. 1783] Berk. C.P. 57 (new agreement pleaded in protestando, but plea never brought to issue).

${ }^{203}$ Howe v. Mackay, 22 Mass. (5 Pick.) 44, 50 (1827).

${ }^{204}$ See Pepoon v. Porter, [Sept. 1795] Hamp. S.J.C. 235 (jury verdict that deputy not guilty); Greenleaf v. Sibley, [Apr. 1792] Worc. S.J.C. 46 (jury verdict that deputy guilty); Brown v. Henderson, [Feb. 1792] Suff. S.J.C: 19 (jury verdict that deputy guilty 
bailees for negligent treatment of or failure to return the plaintiff's goods; ${ }^{205}$ and in suits for fraud or breach of warranty, ${ }^{206}$ of pleading either not guilty or never promised. A defendant could, that is, treat an action either as one in tort or as one in contract whenever the nature of the suit was unclear. Similarly, if a writ, such as assumpsit, to which never promised was the proper general issue, were brought upon a cause of action, such as breach of promise to marry, to which the tort issue of not guilty was the proper response, the tort issue had to be pleaded. ${ }^{207}$ Courts, in short, no longer thought in terms of specific pleas as answers to specific writs; rather they thought in terms of the underlying nature of the cause of action and, accordingly, required defendants to plead in an appropriately responsive manner. ${ }^{208}$

of neglect of duty); Hurd v. Henderson, [Feb. 1788] Suff. S.J.C. 329 (jury verdict that deputy guilty in part); Hills v. Baldwin, [Oct. 1787] Msex. S.J.C. 285 (jury verdict that deputy guilty); Brown v. Hyde, [Oct. 1785] Berk. S.J.C. 191 (jury verdict of not guilty on writ of case against sheriff which included allegation that the sheriff had promised to serve an execution); Brooks v. Burroughs, [Jan. 1799] Suff. C.P. 182 (plea of never promised upheld); Sloane v. Henderson, [Oct. 1791] Suff. C.P. 72 (plea that sheriff not liable for deputy's promises and that deputy never promised upheld).

${ }^{20.5}$ See Wood v. Wood, [Nov. 1808] Suff. S.J.C. 15 (jury verdict that defendant promised); Child v. Merry, [Feb. 1799] Suff. S.J.C. 117 (same); Fisk v. Caldwell, [Apr. 1798] Worc. S.J.C. 99 (jury verdict of guilty); Niles v. Prince, [Feb. 1794] Suff. S.J.C. 11 (jury verdict that defendant promised); Hulbert v. Houghton, [Aug. 181.5] Frank. C.P. 30 (jury verdict of not guilty upon plea of never promised); Pinkham v. Griffin, [July 1807] Suff. C.P. 442 (jury verdict of not guilty); Pope v. Godshall, [June 1805] Essex C.P. 158 (plea of never promised upheld); Cushing v. Davis, [Mar. 1805].Essex C.P. 70, appeal dismissed, [Apr. 1805] Essex S.J.C. 388 (plea of not guilty upheld); Niles v. Capt, [Oct. 1796] Suff. C.P. 206, appeal dismissed, [Feb. 1797] Suff. S.J.C. 18 (plea of not guilty upheld); Evans v. Linkon, [Dec. 1784] Bris. C.P. 431 (jury verdict on plea of not guilty).

${ }^{206}$ Wilson v. Dunlap, [June 1797] Essex S.J.C. 139 (jury verdict of not guilty); Steel v. Billings, [Oct. 1795] Berk. S.J.C. 255 (same); Webb v. Cross, [June 1795] Cumb. S.J.C. 145 (jury verdict of guilty); Gray v. Bordman, [Feb. 1795] Suff. S.J.C. 10 (jury verdict of not guilty); Smith v. Whitney, [Aug. 1824] Hampd. C.P. 23 (jury verdict that defendant promised); Briggs v. Atwood, [Nov. 1807] Ply. C.P. 59 (jury verdict of guilty); Denny v. March, [Sept. 180.5] Worc. C.P. 269, appeal dismissed, [Sept. 1806] Worc. S.J.C. 409 (jury verdict of not guilty); Newhall v. Eaton, [Apr. 1805] Bris. C.P. 200, appeal dismissed, [Oct. 1806] Bris. S.J.C. 380 (same); Fennelly v. Lee, [Jan. 1805] Suff. C.P. 126, rev'd on defaulth [Nov. 1806] Suff. S.J.C. 244 (plea of never promised upheld); Martins v. Walter, [Jan. 1805] Suff. C.P. 57, appeal dismissed, [Nov. 1806] Suff. S.J.C. 202 (plea of not guilty upheld); Welsh v. Gridley, [Oct. 1799] Suff. C.P. 287, appeal dismissed, [Aug. 1801] Suff. S.J.C. 167 (plea of never promised upheld); Vernon v. Gay, [Oct. 1797] Suff. C.P. 24., appeal dismissed, [Feb. 1799] Suff. S.J.C. 113 (same); Foster v. Pope, [Sept. 1797] Berk. C.P. 343, appeal dismissed, [Oct. 1799] Berk. S.J.C. 239 (jury verdict of guilty); Train v. Henshaw, [Dec. 1783] Worc. C.P. 294 (jury verdict of not guilty).

${ }^{207}$ See Ferre v. Wallis, [Nov. 1808] Hamp. C.P. 272, appeal dismissed, [Apr. 1810] Hamp. S.J.C. 205; Wells v. Chase, [June 1804] Essex C.P. 224; Twiss v. Perry, [Sept. 1785 Essex C.P. 345, appeal dismissed, [June 1786] Essex S.J.C. 243.

${ }^{208}$ For other examples of pleas to suits on the borderline between tort and contract, see Hurd v. Silk, [May 1792] Barns. S.J.C. 100 (jury verdict of guilty upon a writ of case for defendant's failure to pay plaintiff wages due for hiring of his servant); Tufts v. Apthorp, [Feb. 1788] Suff. S.J.C. 324 (jury verdict that defendant never promised upon 
Emerging concepts of tort and contract also caused the development of other pleading rules, such as the rule that counts in tort and contract could not be joined ${ }^{209}$ that joint victims of a single act of misfeasance could not join their claims in tort, although joint promisees could join claims in contract; ${ }^{210}$ and that joint tortfeasors could plead separately in defense, while joint promisors could not. ${ }^{211}$

Concepts of tort and contract were not, of course, entirely new in post-Revolutionary Massachusetts; the pre-Revolutionary records had contained occasional references to them. ${ }^{212}$ What was new in the post-Revolutionary period was the emphasis on substance over form and the rejection of British forms-that is, the writ system - as an intellectually acceptable mode of thinking about law. Once the old formulary categories had been rejected, new categories had to replace them, and Massachusetts lawyers turned to substantive categories, to which they adapted the ancient forms of action and their ancient defenses. That adaptation was, however, but a single step along the path from common law pleading to the modern Massachusetts variant of code pleading.

\section{THE DEVELOPMENT OF A UNITARY DEFENSIVE PLEA}

The next step in the reform of common law pleading was the development during the first two decades of the nineteenth century of a unitary defensive plea under which a defendant could introduce whatever facts constituted a defense on the merits to the plaintiff's cause of action. A part of this development was the recognition that the particular varieties of

writ of case for breach of promise made by defendant's agent); Abrahams v. Hays, [June 1787] Linc. S.J.C. 162 (jury verdict of not guilty upon writ of case for failure of broker to deliver insurance policy to plaintiff); Maccarty v. Fifth Mass. Tpke. Corp., [Mar. 1805] Worc. C.P. 79, appeal dismissed, [Sept. 1805] Worc. S.J.C. 353 (plea of not guilty upheld upon writ of case for defect in turnpike encountered after paying toll); Thomas v. Lunt, [Sept. 1785] Essex C.P. 313 (jury verdict of guilty in plea of case alleging negligence on part of defendant contrary to his promise). See also Hill v. Inhabitants of Shutesbury, [May 1786] Hamp. S.J.C. 190 (jury verdict that defendant not guilty but did promise upon writ of case by minister for salary).

${ }^{209}$ White v. Snell, 22 Mass. (5 Pick.) 425, 427 (1827). But see Remick v. Wyatt, [Dec. 1813] Essex C.P. 257 (denying motion to arrest judgment for improper joinder of tort and contract).

${ }^{210}$ Baker v. Jewell, 6 Mass. 460, 462 (1810).

${ }^{211}$ Meagher v. Bachelder, 6 Mass. 444 (1810). On joinder of parties generally, see note 101 supra.

${ }^{212}$ See W. Nelson, supra note 63 , at 129 n.165. 
the general issue appropriate to particular actions were mere matters of form and that a plea of the wrong general issue was, as a general rule, immaterial. Thus, in the courts of common pleas, where litigation as to the propriety of a particular general issue was usually a matter solely of which party would be appellant and which party respondent in proceedings in the Supreme Judicial Court, judges began around 1800 to regard pleas of the general issue as purely fictitious and to determine on a basis not disclosed in the records ${ }^{213}$ which party would have to take the appeal. This development can be seen first in the courts' upholding of unusual pleas-pleas, for example, of never promised to a writ of trover for conversion ${ }^{214}$ or to a writ of debt for a statutory penalty ${ }^{215}$ of not the defendant's act and deed to a writ of ejectment in which the plaintiff claimed under a deed; ${ }^{216}$ of never accepted to a writ of case against an alleged acceptor of a bill of exchange; ${ }^{217}$ and of "he is not answerable" to a writ of case against a sheriff who wrongfully released property taken on an attachment. ${ }^{218}$ It can be observed subsequently in the inconsistency with which courts dealt with pleas of never promised $^{219}$ and not guilty ${ }^{220}$ made in response to writs of assumpsit; and, finally, in the ultimate result achieved in the 1810 's, when litigants could simply agree without a plea on the part of the defendant to appeal the case to the Supreme Judicial Court. $^{221}$

${ }^{213}$ But see VanSchaack v. Watson, [Jan. 1812] Hamp. C.P. 131, appeal dismissed, [Apr. 1812] Hamp. S.J.C. 303 (defendant's plea rejected because interposed only for delay).

${ }_{214}$ See Hayward v. Weston, [Apr. 1802] Ply. C.P. 372, appeal dismissed, [June 1803] Ply. S.J.C. 169.

${ }^{215}$ See Hinds v. Raymond, [Nov. 1800] Ply. C.P. 161, appeal dismissed, [June 1801] Ply. S.J.C. 108.

216 See Hussey v. Coffin, [Oct. 1796] Nan. C.P. 118.

${ }^{217}$ See Barnes v. Peck, [July 1810] Suff. C.P. 72, rev'd on other grounds, [Nov. 1810] Suff. S.j.C. 200 (jury verdict on appeal that defendant did promise).

${ }^{218}$ See Sewall v. Mattoon, [Oct. 1811] Suff. C.P. 385, rev'd on default, [Mar. 1813] Suff. S.J.C. 142.

${ }_{219}$ Compare, e.g., Goodwin v. Woodbridge, [Sept. 1797] Berk. C.P. 432 (plea of never promised rejected], with Allen v. Lathrop, [July 1805] Suff. C.P. 211, rev'd on defaulh, fNov. 1806l Suff. S.J.C. 341 (plea of never promised upheld).

${ }^{220}$ Compare Hutchins v. Low, [Apr. 1817] Sutt. C.P. 290; Jenkins v. Hanley, Uan. 1803] Berk. C.P. 207, appeal dismissed, [May 1803] Berk. S.J.C. 165 (pleas of not guilty rejected), with Phelps v. Adams, [Mar. 1814] Essex C.P. 55, appeal dismissed, [Nov. 1814] Essex S.J.C. 106; Bond v. Blackmore, [Apr. 1808] Suff. C.P. 336; Brown v. Spaulding, [Oct. 1807] Suff. C.P. 25; Farrar v. King, [Mar. 1807] Worc. C.P. 434, appeal dismissed, [Apr. 1807] Worc. S.j.C. 429; Wendell v. McMullen, [Oct. 1806] Suff. C.P. 172, appeal dismissed, [Nov. 1806] Suff. S.J.C. 712; Scott v. Hodge, [Oct. 1805] Suff. C.P. 538; Dwight v. Webster, [Sept. 1797] Berk. C.P. 2, affd, [Oct. 1797] Berk. S.J.C. 48 (pleas of not guilty upheld).

${ }^{221}$ See Griffin v. Brown, [Oct. 1822] Berk. C.P. 360, affd, [May 1826] Berk. S.J.C. 330. See also Parker v. Thompson, [Oct. 1824] Suff. C.P. 279, rev'd on other grounds, [Mar. 1825] Suff. S.J.C. 177; Davis v. Winegar, [Feb. 1821] Berk. C.P. 191, affd, [Sept. 1824] 
Incorrect pleas of the general issue also came to be treated as harmless formal errors even when they formed the basis of a jury verdict. It appears, for example, that as early as the 1780's a plea of an incorrect general issue would be cured by the jury's return of a verdict upon the proper issue. ${ }^{222}$ The basic rule was that defects of form caused by a failure to adhere to "the strict rules of pleading" could be objected to only upon demurrer and that an "objection . . . [after a verdict came] too late."223 Later, in the early years of the nineteenth century, the courts also arrived at a rule that an informal verdict rendered upon proper pleadings would not be permitted to affect the outcome of the litigation. When " $\mathrm{t}]$ he only error or mistake arose from a mere slip in drawing up the verdict ...," that slip "clearly ... ought not to be allowed to vacate the judgment."224 Even when both the pleadings and the verdict were technically informal, a court might render judgment on the verdict, ${ }^{225}$ particularly if the losing party had been at fault in causing the informality. ${ }^{226}$ The procedure in such a case would be for the court to read the verdict to the jury in proper form and, if the jurors unanimously

Berk. S.J.C. 211; Marsh v. Gold, [Feb. 1821] Berk. C.P. 1, affd, [May 1824] Berk. S.J.C. 86; Perkins v. Wetherell, [Aug. 1814] Ply. C.P. 21, affd, [Oct. 1814] Ply. S.J.C. 72; Curtis v. Curtis, [Dec. 1812] Norf. C.P. 492, appeal dismissed, [Oct. 1814] Norf. S.J.C. 515; Windsor v. Rich, [Apr. 1810] Ply. C.P. 44, affd, [Oct. 1810] Ply. S.J.C. 21. Cf. Chapman v. Eldredge, [Feb. 1826] Berk. C.P. 74, modified, [Sept. 1825] Berk. S.J.C. 273 (parties agree without joining issue on merits that jury may assess damages).

${ }^{222}$ See Briggs v. Braley, [Aug. 1828] Ply. C.P. 69, rev'd on default [May 1830] Ply. S.J.C. 407 (jury verdict of guilty in case for defamation upon plea that defendant "is not of the premises"); Sunkes v. Russell, [Oct. 1827] Suff. C.P. 177 (jury verdict in assumpsit that defendant promised upon plea of not guilty); Fellows v. Dwight, [Feb. 1791] Berk. C.P. 441 (jury verdict in assumpsit that defendant never promised upon plea of not guilty); Warner v. Gustine, [Feb. 1783] Hamp. C.P. 111 (jury verdict in indebitatus assumpsit that defendant never promised upon a plea of not guilty); Warner v. Gustine, [Nov. 1782] Hamp. C.P. 106 (same case). But see Gerrish v. Train, [Jan. 1825] Suff. C.P. 29, appeal dismissed, [Mar. 1827] Suff. S.J.C. 186 (jury verdict of not guilty upon immaterial issue in trespass rejected).

${ }^{223}$ Wheeler v. Train, 20 Mass. (3 Pick.) 255, 258 (1825). See Williams v. Woodman, 25 Mass. (8 Pick.) 78 (1829) (joining issue upon informal plea constitutes waiver of any objection as to its form); Whiting v. Cochran, 9 Mass. 532 (1813) (appearance, defense and jury verdict on issue tendered by plaintiff cures defendant's failure to join therein) (dictum). Cf. Barnard v. Whiting, 7 Mass. 358 (1811) (jury verdict upon good count in plaintiff's declaration cures defective count for same cause of action); Patten v. Gurney, 17 Mass. 182, 187 (1821) (same).

${ }^{224}$ Clark v. Lamb, 25 Mass. (8 Pick.) 415, 418 (1829). Accord, Porter v. Rummery, 10 Mass. 64, 66 (1813); McMasters v. Parsons, [June 1794] Essex S.J.C. 112 (verdict "in favor of the Plaintiffs"); Wilbur v. Reed, [June 1829] Bris. C.P. 118 (verdict for plaintiff which failed to award damages upon plea of tender); Wilbour v. Howard, [Sept. 1826] Bris. C.P. 176 (verdict in assumpsit of not guilty upon a plea of never promised); Hakes v. Hubbell, [Oct. 1822] Berk. C.P. 353, affd, [Sept. 1823] Berk. S.J.C. 53 (verdict in case for defamation that defendant indebted upon plea of not guilty).

${ }^{225}$ See Russell v. Kinney, [Dec. 1821] Bris. C.P. 30 (verdict in assumpsit of not guilty upon plea of not guilty); Lowden v. Lowden, [Nov. 1807] Ply. C.P. 58 (same).

${ }^{226}$ See Eaton v. Stone, 7 Mass. 312, 314 (1811). 
agreed to that verdict, the court would then "authorize it to be recorded." ${ }^{227}$ The court would not render judgment, however, if the pleadings were so defective that the court was at a loss as to what judgment to render. ${ }^{228}$

The general issue was not the only defensive plea to undergo modification during the closing years of the eighteenth and opening years of the nineteenth century; the rules for special pleading were also modified. First, a series of statutes in the last two decades of the eighteenth century gave liberty to specified categories of defendants to plead the general issue and to put special matter in evidence thereunder. These laws applied to all defendants in actions before justices of the peace except suits involving title to land, ${ }^{229}$ executors, administrators and guardians; ${ }^{230}$ and justices of the peace, sheriffs and other local officials. ${ }^{231}$ These statutes sought to assist these defendants in avoiding the vagaries of special pleading. ${ }^{232}$ Judicially-created rules offered similar assistance to other defendants. One rule permitted a defendant upon a plea of the general issue to reserve with the plaintiff's consent the right to put special matters in evidence. ${ }^{233}$ A second practice-pleading double-permitted a defendant to join a special plea to a plea of the general issue, ${ }^{234}$ even if the two pleas were inconsistent. ${ }^{235}$ Since the general issue

${ }^{227}$ Ropps v. Barker, 21 Mass. (4 Pick.) 239, 242 (1826).

${ }^{228}$ See Gerrish v. Train, 20 Mass. (3 Pick.) 124, 127 (1825); Newburyport v. Adams, [June 1785] Essex S.J.C. 239 (verdict failed to disclose land taken for road so that damages could not be determined).

${ }^{229}$ Act of Mar. 11, 1784, $\S \S 2,77,1$ [1784-1807] Mass. Laws 146, 147, 149, construed, Waters v. Lilley, 21 Mass. (4 Pick.) 145 (1826). For the general rule that a defendant could not introduce matters involving title to land into evidence in trespass actions commenced before justices of the peace, see Lynch v. Rossetter, 23 Mass. (6 Pick.) 419 (1828).

${ }^{230}$ Act of Mar. 10, 1784, $§ 9,1$ [1784-1807] Mass. Laws 134, 137, construed, Foster v. Abbott, 1 Mass. 234 (1804).

${ }^{231}$ Act of Feb. 25, 1793, 2 [1784-1807] Mass. Laws 560, construed, Bangs v. Snow, 1 Mass. 181 (1804). This statute was also applied in Stearns v. Merwin, [Nov. 1826] Hampd. C.P. 8; Drake v. Hewins, [Feb. 1819] Norf. S.J.C. 17; Whipple v. Chamberlain, [Oct. 1815] Suff. C.P. 207; Lamson v. Calley, [Dec. 1813] Essex C.P. 424.

${ }^{232} \mathrm{See}$ Howe Lectures, supra note 105, at 181-82.

${ }^{233}$ See Pierre v. McCrellis, [Apr. 1800] Hampd. S.J.C. 256; Hall v. Fletcher, [Sept. 1792] Msex. C.P. 39. But see Kellogg v. Ingersoll, 1 Mass. 5 (1804) (special matter not allowed in evidence under plea of non est factum to writ of covenant).

${ }^{234}$ Merry v. Gay, 20 Mass. (3 Pick.) 388 (1826); see Baker v. Prescott, [Mar. 1826] Suff. S.J.C. 66; Sanderson v. Henderson, [Feb. 1792] Suff. S.J.C. 6; Breed v. Hurd, [Oct. 1827] Suff. C.P. 122, rev'd on other grounds, [Mar. 1828] Suff. S.J.C. 105; Stratton v. Whitney, [Sept. 1816] Worc. C.P. 322; Raymond v. Braman, [Sept. 1805] Bris. C.P. 242, appeal dismissed, [Oct. 1806] Bris. S.J.C. 380. But see Martin v. Woods, 6 Mass. 6 (1809) (defendant may not plead in special plea a fact which he must already prove under general issue to which special plea is joined); DeLuce v. DeGuiscard, [Aug. 1783] Suff. S.J.C. 154 (motion in writ of case for defamation for leave to plead general issue and special justification overruled).

${ }^{23.5}$ Merry v. Gay, 20 Mass. (3 Pick.) 388, 389 (1826). 
would always be a sufficient defense, a defendant, by joining a special plea to it, obtained the benefits of the special plea without undergoing the risk of being thrown out of court as a result of a formal, technical error in it. Although theoretically a matter of discretion, "leave to plead double [was] granted almost as a matter of course, \& without much consideration . . . ."236 Moreover, in cases where a special plea was joined to the general issue, juries usually returned, and the courts then rendered judgment upon, a verdict which decided only the general issue. ${ }^{237}$ The courts reasoned that the jury could not have decided the general issue without implicitly deciding the special issue as well. ${ }^{238}$ In short, special pleas were completely ignored, except to give defendants who joined special to their general pleas the right to put special matter in evidence under the general issue. Special pleading was virtually abolished. Old rules of special pleading survived only where defendants pleaded specially without simultaneously pleading the general issue. ${ }^{239}$

${ }^{236}$ Howe Lectures, supra note 105 , at 141.

${ }^{237}$ See Hildreth v. Winslow, [Apr. 1790] Worc. S.J.C. 74; Chase v. Patterson, [June 1788] York S.J.C. 418; Wood v. Stevens, [June 1786] Cumb. S.J.C. 280; Wood v. Hinckley, [July 1821] Suff. C.P. 50, affd, [Nov. 1821] Suff. S.J.C. 214; McElwain v. Lyon, [Aug. 1801] Hampd. C.P. 116; Freeman v. Norman, [July 1785] Suff. C.P. 40, rev'd on defaulh [Feb. 1786] Suff. S.J.C. 42; Howe Lectures, supra note 105, at 199-200.

${ }^{238}$ Hodges v. Raymond, 9 Mass. 316 (1812).

${ }^{239} \mathrm{~A}$ basic rule of special pleading which so survived was that a defendant could not plead specially facts which merely "amounted to the general issue"-that is, "facts [which] would be proper evidence under [such an issue]." Town of Freeport v. Town of Edgecumbe, 1 Mass. 459, 462 (1805). Accord, Ely v. Granger, [Sept. 1794] Hampd. C.P. 293. Since in most writs "the defendant may give in evidence under the general issue any matter that contradicts the allegations which the plaintiff is bound to prove," a defendant had to plead specially "matters of excuse or justification" and other special defenses. Rawson v. Morse, 21 Mass. (4 Pick.) 127 (1826). For examples of matters which were admissible under the general issue and hence could not be pleaded specially, see Poor v. Robinson, 10 Mass. 131, 134 (1813) (all evidence with exception of collateral warranty in writ of right); Proprietors of Monumoi Great Beach v. Rogers, 1 Mass. 159, 160 (1804) (dictum) (evidence of title in trespass q.c.f.); Hayward v. Parris, [Nov. 1799] Ply. C.P. 6 (evidence in assumpsit that contract never made); Campbell v. Jones, [May 1779] Hampd. C.P. 236 (same); Boardman v. Barton, [Jan. 1793] Suff. C.P. 45 (evidence in trespass for assault that defendant did not wound plaintiff); Waitt v. Clap, [Sept. 1788] Essex C.P. 87 (evidence of fraud in endorsement of note). For examples of matters which were not admissible under the general issue and hence could be pleaded specially, see Wolcott v. Knight, 6 Mass. 418, 420 (1810) (evidence of conveyance by ancestor of demandant after disseisin not admissible under general issue in entry); Pray v. Pierce, 7 Mass. 381, 383 (1811) (evidence that defendant is not freehold tenant); Kelleran v. Brown, 4 Mass. 443, 444 (1808) (same); M'Farland v. Barker, 1 Mass. 153 (1804) (special matter in justification not admissible under general issue in replevin); Noble v. Talcot, [Oct. 1796] Berk. S.J.C. 265 (payment, discharge, or accord and satisfaction); Padelford v. Cobb, [May 1790] Ply. S.J.C. 100 (same); Weld v. Needham, [Nov. 1809] Hampd. C.P. 321, appeal dismissed [Âpr. 1810] Hampd. S.J.C. 214 (same); Parry v. Daman, [Jan. 1806] Suff. C.P. 55 (same); Parker v. Grout, [Oct. 1800] Suff. C.P. 58 (same); Allen v. Minot, [July 1790] Suff. C.P. 21 (same); Saltmarsh v. Willington, [Sept. 1787] Essex C.P. 213 (same); VanDusen v. Williams, [Sept. 1784] Berk. C.P. 456 


\section{THE TRANSFORMATION TO NOTICE PLEADING}

During the first third of the nineteenth century, then, the rules of pleading were transformed. In cases in which the common law system proved constraining, litigants were no longer held to its constraints but were able to bend the system to fit the needs of their case. If a plaintiff had a just claim or a defendant a just defense, technical rules of pleading would no longer be interposed to prevent adjudication on the merits. Pleadings no longer had to adhere to the ancient forms; the only requirement of a pleading was that it give "notice to the opposing party, of matters intended to be given in evidence by either party to a suit, as shall be necessary to prevent surprise, and to afford opportunity for preparation for trial,, 240 for a party could "not be supposed to come prepared to defend against any cause of action [or defense], of which he ha[d] no notice in the declaration" or in the plea in response thereto. ${ }^{241}$

The courts had thus travelled most of the distance toward a system of notice pleading by 1830 , and the legislature soon thereafter intervened and completed the task by statutes enacted in 1836 and 1851 . The 1851 act, which was the result of study by a commission of eminent lawyers appointed within a year of the enactment of the Field Code in New York, ${ }^{242}$ was the Massachusetts alternative to a code. ${ }^{243}$ Like the Field Code, the 1851 act formally abolished the individual common law writs in personal actions, but it did not substitute a single, unitary cause of action for them. Instead it created generic pleas of contract,

(same); Bates v. Googins, [Nov. 1792] Essex S.J.C. 291 (tender); Robbins v. Luce, [Apr. 1806] Berk. C.P. 291, affd, [Sept. 1808] Berk. S.J.C. 502 (same); Drury v. Knowles, [July 1785] Suff. C.P. 10 (same); Almy v. Bacon, [Apr. 1826] Bris. S.J.C. 147 (fraud or duress); Stevenson v. Edey, [Mar. 1813] Suff. C.P. 47 (same); Holmes v. Allen, Uan 1809] Hampd. C.P. 63 (same); Cornish v. Allen, [Sept. 1794] Berk. C.P. 81 (same); Hooper v. Putnam, [A pr. 1785] Essex C.P. 17 (performance of conditions of bond); Poor v. Downer, [June 1786] Essex S.J.C. 242 (justification for defamation); Cunningham v. Barnes, [July 1787] Suff. C.P. 122, appeal dismissed, [Feb. 1788] Suff. S.J.C. 335 (justification for assault). But see Dawes v. Gooch, 8 Mass. 488 (1812). Another rule which survived was that a defendant could not plead parol evidence which varied a written contract, nor could he put such evidence in under the general issue. See Sibley v. Brown, 21 Mass. (4 Pick.) 137 (1826); Jacobs v. Putnam, 21 Mass. (4 Pick.) 108 (1826); Townsend v. Weld, 8 Mass. 146 (1811); Barnard v. Titcomb, [July 1790] Essex C.P. 7. On the limits of the parol evidence rule, see generally Comstock v. Van Deusen, 22 Mass.

(5 Pick.) 163 (1827); Leland v. Stone, 10 Mass. 459 (1813).

${ }^{240}$ Act of Apr. 16, 1836, ch. 273, §2, [1836] Mass. Laws 1000.

${ }^{241}$ Sampson v. Coy, 15 Mass. 493,494 (1819); accord, Hemmenway v. Woods, 18 Mass. (1 Pick.) 524 (1823).

${ }^{242}$ See 13 L. REP. 481 (1851).

${ }^{243}$ See 14 L. REV. \& Q.J. BRIT. \& FOR.JUR. 143 (1851). 
tort and replevin for litigating personal actions ${ }^{244}$ which took their place alongside the ancient generic plea of land used in real actions. In addition, the 1836 act, passed during the course of earlier study of the state's law by a similarly eminent commission, ${ }^{245}$ had confirmed the earlier judicial abolition of special pleading and provided further that "all matters of law or of fact in defence of [an] action [could] be given in evidence under the general issue ...."246

Long before this legislation, though, the abolition of common law pleading had begun to have consequences which were often unforeseen and which required compensatory modification of other rules of law. One advantage of common law pleading is that, in addition to giving parties notice of the essence of each other's claims, it narrows the issues that can arise upon trial by requiring parties to select before trial, at least in part, the legal theory they plan to pursue. Particularly if the parties have engaged in special pleading, the issues on which litigation will turn will be precisely identified before trial begins. With the abolition of common law pleading, however, issues were no longer formulated and defined before trial but during the very course of trial, as the parties offered evidence and made legal contentions on the basis of that evidence.

Two problems arose. One came in determining the res judicata effect of prior judgments where facts had been put in issue by means other than pleadings and hence were not of record. ${ }^{247}$ The other problem was that preparation for trial became more difficult and hazardous. As one defendant argued, the complaint to which he had to respond was "so general, that it

${ }^{244}$ Act of May 22, 1851, ch. 233, $§ 1$, [185i] Mass. Laws 698 . The 1851 Law was repealed in 1852 and was replaced by Act of May 22, 1852, ch. 312, $\S 1$, [1852] Mass. Laws 223, which retained the 1851 reforms and added certain other reforms as well. For a discussion of the additions in the 1852 law, see 15 L. REP. 112 (1853).

${ }^{245}$ See J. STORY, $A$ Report of the Commissioners Appointed to Consider and Report Upon the Practicability and Expediency of Reducing to a Written and Systematic Code the Common Law of Massachusetts, or Any Part Thereof, in Miscellaneous WRITINGS OF JOSEPH STORY 698, 728 (W. Story ed. 1852) (Da Capo Press reprint 1972). Justice Story headed the Commission which finally recommended not the codification of the law of pleading, but its reduction to a simpler form.

${ }_{246}$ Act of Apr. 16, 1836, ch. 273, § 1, [1836] Mass. Laws 1000.

${ }^{247}$ For cases in which the Supreme Judicial Court, in great confusion, struggled with this question, see Parker v. Standish, 20 Mass. (3 Pick.) 288 (1825); Standish v. Parker, 19 Mass. (2 Pick.) 20 (1823). Its problem was that the appropriate mode for determining the existence and scope of a prior judgment was for the court to inspect the record. See Bellows v. Hosmer, [Sept. 1820] Msex. C.P. Files, rev'd on default [Oct. 1820] Msex. S.J.C. 110. But cf. Hayden v. Shed, [Nov. 1814] Msex. S.J.C. 52 (jury verdict for plaintiff in trespass for seizing property previously seized upon prior suit for same cause of action). 
[was] impossible [that] any man [could] prepare to defend himself in the same...." ${ }^{448}$ Whereas litigants at common law had often had to prepare evidence only upon a small number of precisely defined issues, a litigant under the new pleading system had to prepare to meet many potential issues, only some of which would arise. "Causes of great importance" came, as one commentator noted, "often to be tried by a Jury merely upon the general isssue, when the facts [were] complicated \& intricate, the evidence of great length \& variety \& some times contradictory, $\&$ where questions of great nicety \& difficulty [were] involved in the discussion." ${ }^{249}$ Moreover, a litigant faced the danger that issues which he had never anticipated might nevertheless arise and that he might "be surprised by a piece of evidence which at another time he could have explained or answered."250

In order to ensure that parties would "not [be so] surprised by new matter," ${ }^{251}$ new procedural rules had to be formulated. Thus, the courts prohibited the admission of evidence to which there was an objection of surprise, ${ }^{252}$ and provided, even after a verdict had been returned, for " $a$ new trial, in case either party be unfairly surprised by the other." 253 The hazards of preparing for trial without being able to anticipate with certainty the issues that would arise also compelled the courts to develop rules authorizing the granting, after verdict, of a new trial on the ground of newly discovered evidence ${ }^{254}$ which was material to the issue ${ }^{255}$ was not merely cumulative, ${ }^{256}$ and had not remained

${ }^{248}$ Kelton v. Butler, [Jan. 1801] Suff. C.P. 186.

${ }^{249}$ Howe Lectures supra note 105 , at 336 .

${ }^{250} I d$.

${ }^{251}$ Vining v. Whiting, (Suff. S.J.C. 1796), in Dana, supra note 97.

${ }^{252}$ Sylvester v. Bailey, (Ply. S.J.C. 1790), in Dana, supra note 97.

2533 W. Blackstone, COMmENTARIES *306; accord, Boston Gazette, May 13, 1782, at 1, col. 1 (quoting Blackstone). See also Taylor v. Parsons, [Dec. 1816] Essex C.P. 493; Quirk v. Mingus, [Sept. 1810] Norf. C.P. 247; Mason v. Payson, [Mar. 1805] Msex. C.P. 11 (movants for new trials claimed surprise but were unable to make sufficient demonstrations thereof on the facts).

${ }^{254}$ See Chatfield v. Lathrop, 23 Mass. (6 Pick.) 417 (1828); Niles v. Brackett, 15 Mass. 378 (1819); Starbuck v. Coffin, [Oct. 1825] Nan. C.P. 210. See also Bond v. Humphrey, [July 1828] Suff. C.P. 85; Sylvester v. Wood, [Sept. 1814] Bris. C.P. 130; Taylor v. Stone, [Dec. 1813] Msex. C.P. Files; Paddock v. Holbrook, [Mar. 1811] Worc. C.P. 536; Ford v. Haley, [Dec. 1808] Msex. C.P. Files; Hager v. Weston, [Dec. 1807] Msex. C.P. Files, rev'd on other grounds, [Oct. 1810] Msex. S.J.C. 91 (litigants sought new trials on the basis of newly discovered evidence but failed to make the requisite showing therefor); Petition of Coffin, [Oct. 1805] Nan. C.P. 352 (no disposition of application for new trial). See generally Howe Lectures, supra note 105, at 376-83.

${ }_{255}$ See Tuttle v. Cooper, 22 Mass. (5 Pick.) 414 (1827).

${ }^{256}$ See Chatfield v. Lathrop, 23 Mass. (6 Pick.) 417, 418 (1828); Gardner v. Mitchell, 23 Mass. (6 Pick.) 114, 116 (1828). 
undiscovered through fault of the movant. ${ }^{257}$ Newly discovered evidence became, in fact, "the most common cause for granting new trials." 258 As a general matter, new trials were granted whenever a party had not had adequate opportunity to present his claim. ${ }^{259}$ (1809).

${ }^{257}$ See Bond v. Cutler, 7 Mass. 205 (1810); Hammond v. Wadhams, 5 Mass. 353

${ }^{258}$ Howe Lectures, supra note 105 , at 376 . New trials continued to be granted for various sorts of misconduct on the part of jurors or because juries were improperly composed. See Commonwealth v. Hussey, 13 Mass. 221 (1816) (petit juror also member of grand jury returning indictment); Knight v. Inhabitants of Freeport, 13 Mass. 218 (1816) (son-in-law of party spoke with juror); Prescott v. Spring, [Apr. 1797] Msex. S.J.C. 45 (juror absent during part of deliberations); Commonwealth v. Cooms, [Nov. 1786] Essex S.J.C. 465 (jurors separated during deliberations); Wait v. Boston \& Roxbury Mill Corp., [Dec. 1821] Norf. C.P. 317 (juror related to plaintiff); Commonwealth v, Godfrey, [Sept. 1821] Norf. C.P. 247 (no jury foreman chosen); Hubbard v. Hartwell, [Feb. 1821] Berk. C.P. 418 (juror discussed case with nonjurors prior to verdict); Youlin v. Cogswell, [Dec. 1817] Essex C.P. 543 (juror in paternity case a resident of town in which plaintiff a pauper); White v. Bodwell, [Sept. 1805] Essex C.P. 22.5 (jury in road case held before deputy sheriff instead of sheriff); Saxon v. Vinall, [Oct. 1802] Suff. C.P. 153 (jurors had out-of-court conversation prior to verdict); Petition of Newhall, [Oct. 1806] Essex G.S. 180 (jurors improperly summoned). Cf. Highway in Cambridge, [Sept. 1803] Msex. G.S. 201 (report of road committee rejected since a member thereof "not a disinterested freeholder, he having real estate" in town paying for road). But see Washburn v. Inhabitants of Middleboro, [Nov. 1828] Ply. C.P. 118 (motion on ground that officer in charge of jury was an inhabitant of defendant's town overruled); Wood v. Souther, [Mar. 1825] Msex. C.P. Files (motion on ground that magistrate to whom complaint was made in paternity case was an inhabitant of plaintiff's town overruled); Anthony v. Briggs, [Sept. 1820] Bris. C.P. 142 (motion on ground that juror was a nephew of plaintiff overruled); Butterfield v. Mason, [Mar. 1820] Msex. C.P. Files (motion on ground that juror was related to defendant overruled); Hincher v. Howland, [Dec. 1819] Worc. C.P. 322(motion on ground that juror was absent during evidence, argument and deliberations overruled after hearing); Batterman v. Bell, [Dec. 1812] Suff. C.P. Files (motion on ground that jurors separated during deliberations overruled); White v. Leonard, [Apr. 1811] Norf. C.P. 119 (motion on ground that jurors in paternity case were residents of plaintiff's town overruled); Petition of Lovell, [Sept. 1813] Norf. G.S. 258 (motion on ground that juror was a proprietor in defendant corporation overruled). Other objections to the composition of juries were valid only if seasonably made. Compare Commonwealth v. Knapp, 27 Mass. (10 Pick.) 477, 479-80 (1830) (name of juror not in jury box), and Inhabitants of Amherst v. Inhabitants of Hadley, 18 Mass. (1 Pick.) 38 (1832) (juror's name drawn more than 20 days before court sitting), with Commonwealth v. Knapp, 26 Mass. (9 Pick.) 496, 498-99 (1830) (discussion of propriety of challenges for cause on basis of juror's prior knowledge from newspapers about facts of criminal case).

${ }^{259}$ For other such rules not discussed in the text, see Dunham v. Baxter, 4 Mass. 79 (1808) (new trial granted when defendant prevented by court's ruling from presenting relevant evidence); Leadbetter v. Lovewell, [Sept. 1823] Msex. C.P. Files (new trial granted when defendant suddenly taken seriously ill and therefore unable to attend court); Patten v. Richardson, [Dec. 1821] Norf. C.P. 308 (new trial granted when judgment on default entered by "mistake and accident"); Hall v. Walker, [Jan. 1819] Berk. C.P. 318 (new trial granted when attorney of out-of-state defendant forgot return date of writ); Brooks v. Davis, [Nov. 1813] Worc. C.P. 404 (new trial granted when defendant ill and failed to attend court in belief that nominal party in interest would answer); Brown v. Keith, [June 1813] Worc. C.P. 7 (new trial granted to non-resident who had no knowledge of suit); Petition of Gilbert, [May 1792] Hampd. C.P. 93 (new trial granted when defendant did not know of suit). Cf. Highway in Cambridge, [Nov. 1793] Msex. G.S. 134 (decision on report of road committee postponed when party "unexpectedly deprived of an opportunity of shewing his reasons against the acceptance" 


\section{CONCLUSION}

The unforeseen consequences of the abolition of common law pleading indicate most clearly, perhaps, what was at stake in the nineteenth century movement toward pleading reform and why that reform could not take place overnight as the reformers of the 1780's demanded, and the students of the Field Code thought it did. Although common law pleading was antiquated, unduly technical and expensive, and hence in need of reform, it nonetheless provided a working system for the trial of cases. More important, it provided lawyers with a conceptual framework within which to analyze an otherwise amorphous body of legal rules. Thus, although lawyers in Massachusetts at an early date recognized that the rules of pleading were in need of reform and began to take hesitant steps in that direction, full reform could not occur until new substantive categories for analyzing the law and new procedures for ensuring the fair dispensation of justice were developed. The new modes of thought and the new forms of procedure emerged only slowly; the Massachusetts statutory procedural reforms came not as sudden bursts of creative endeavor but as ratifications of a half century of gradual evolution. ${ }^{260}$ The slow transformation of common law pleading in Massachusetts suggests that the widely held image of the Field Code as a stroke of reforming genius must be reexamined.

thereof). But see Brown v. Bigelow, [Dec. 1823] Worc. C.P. 358 (new trial denied when defendant unable to write plea because of lack of attorney); Jewett v. Lane, [June 1818] Worc. C.P. 607 (new trial denied when bad roads prevented timely arrival of out-of-state litigant); Petition of Chase, [June 1813] Essex C.P. 437 (new trial denied upon claim that original trial held so quickly that defendant lacked opportunity to prepare); Richardson v. Truman, [Oct. 1807] Suff. C.P. Files (new trial denied to defendant when plaintiff, after putting documents in evidence, failed to give copies to defendant to permit rebuttal); Inhabitants of Worcester v. Allen, [Mar. 1825] Worc. G.S. 360 (new trial denied when agent of defendant failed to make arguments which defendant had ordered him to make).

${ }^{260}$ Reform in England, however, does appear to have come rather suddenly and largely as a result of legislation beginning in 1852. See note 2 supra. English procedural reform seems to have come about largely through American influence, as is evidenced by the attention paid by English legal journals to American procedural reforms of the mid-19th century. See 14 [N.S.] L. MAG. 1 (1851); 12 L. REV. \& Q.J. BRIT. \& FOR.JUR. 366 (1850); 13 L. REV. \& Q.J. BRIT. \& FOR.JUR. 65 (1850), 213 (1851); 14 L. REV. \& Q.J. BRIT. \& FOR.JUR. 143, 284 (1851); 17 L. REV. \& QJ. BRIT. \& FOR.JUR. 217, 225 (1852); 18 L. REV. \& Q.J. BRIT. \& FOR. JUR. 217, 426 (1853); 22 L. REV. \& Q.J. BRIT. \& FOR. JUR. 317 (1855). 